\title{
WestVirginiaUniversity
}

THE RESEARCH REPOSITORY @ WVU

Graduate Theses, Dissertations, and Problem Reports

2010

\section{Investigating the potential of RNA to be used in forensic casework analysis}

Tiffany Lynn Smith

West Virginia University

Follow this and additional works at: https://researchrepository.wvu.edu/etd

\section{Recommended Citation}

Smith, Tiffany Lynn, "Investigating the potential of RNA to be used in forensic casework analysis" (2010). Graduate Theses, Dissertations, and Problem Reports. 4658.

https://researchrepository.wvu.edu/etd/4658

This Thesis is protected by copyright and/or related rights. It has been brought to you by the The Research Repository @ WVU with permission from the rights-holder(s). You are free to use this Thesis in any way that is permitted by the copyright and related rights legislation that applies to your use. For other uses you must obtain permission from the rights-holder(s) directly, unless additional rights are indicated by a Creative Commons license in the record and/ or on the work itself. This Thesis has been accepted for inclusion in WVU Graduate Theses, Dissertations, and Problem Reports collection by an authorized administrator of The Research Repository @ WVU. For more information, please contact researchrepository@mail.wvu.edu. 


\title{
Investigating the Potential of RNA to be Used in Forensic Casework Analysis
}

\section{Tiffany Lynn Smith}

\author{
Thesis \\ Submitted to the Eberly College of Arts and Sciences \\ at West Virginia University \\ in partial fulfillment of the requirements \\ for the degree of \\ Master of Science \\ in \\ Cellular and Molecular Biology \\ Committee Members: \\ Clifton Bishop, Ph.D., Chair \\ David Ray, Ph.D. \\ Jeffrey Wells, Ph.D. \\ Department of Biology \\ Morgantown, West Virginia \\ 2010
}

Key Words: Quantitative Reverse-Transcription Real-time PCR, RNA, DNA, Semen, Forensics, Nucleic Acid Isolations, DNase Treatments 


\section{ABSTRACT \\ Investigating the Potential of RNA to be Used in Forensic Casework Analysis}

\section{Tiffany Lynn Smith}

With the advent of quantitative reverse-transcription real-time polymerase chain reaction, RNA has increasingly become an invaluable tool to forensic science investigations. For instance, previous studies have shown that the age of a biological stain could be estimated using differential decay rates of different RNA segments, providing a temporal link between the suspect and the crime. By co-isolating RNA and DNA from the same sample, both a genetic profile and various other analyses can be conducted. RNA samples are frequently treated with DNase prior to analysis to rid samples of contaminating DNA. Although all manufacturers of DNase claim no loss of RNA-derived signal, our results indicate that only those based upon heat inactivation of the DNase showed acceptable levels of signal loss. Loss of cDNA is not permissible for studies where levels of starting RNAs are crucial in obtaining accurate results. Ideally, primers and probes for estimating relative RNA levels will be designed to span exonexon boundaries such that DNA contamination cannot provide a false signal. Unfortunately such primer and probe locations are not always possible. We also investigated the feasibility of using RNA degradation as a means of determining the approximate ex vivo age of semen samples. Our results indicate that, unlike bloodstains and other biological specimens, RNA contained within dried semen samples do not degrade in a predictable fashion after the first few days following deposition. After approximately 1-1.5 years, differential degradation was observed in dried semen stains therefore the use of this technique for exclusionary purposes may be possible. Our results also indicate that primers and probes designed to detect small segments of semen specific RNAs can be used to identify dried semen samples at least 1.5-2 years of ex vivo age. Liquid samples did show differential decay rates shortly after deposition. In conclusion, RNA will likely become a fundamental tool in the near future for forensic investigations but it must be kept in mind that the manufactures claims should be validated before all examinations. 


\section{ACKNOWLEDGEMENTS}

I would like to first thank my advisor, Dr. Clifton Bishop for his guidance and support through all of the trials and tribulations associated with this research. You have allowed me to explore my ideas and were always there for me both professionally and personally. Without your leadership and encouragement I would not have developed as much as a scientist. Secondly, I would like to thank the members of my committee, Dr. Jeffrey Wells and Dr. David Ray, for all of their direction and assistance. I appreciate all the time and collaboration that you have given me throughout the years.

I would like to thank the members of my lab: Stephanie Young, Beatriz Vianna, Swati Banerjee, and Ashley Banks for all of their assistance and friendship. You all have supported, encouraged, and allowed me to bounce ideas off of you and I greatly appreciate it. I would like to thank Regina Trott for all of her help in the beginnings of my studies. Your patience and vast knowledge of laboratory procedures has assisted me tremendously. I would also like to thank Mohna Bandyopadhyay. You have been a great officemate and friend. Your cheerful personality has helped me to enjoy my time here at West Virginia University.

In addition I would like to thank all faculty, staff, and graduate students from the Departments of Biology and Forensic \& Investigative Sciences. Your advice and support is greatly appreciated. To my biological donors, without you this work would not have been possible.

Most importantly, I would like to thank my family and friends. I am grateful for all the support and love you have given me throughout the years and for always believing in me. Your encouragement and patience has given me the strength to make this all possible. 


\section{Table of Contents}

$\begin{array}{ll}\text { Title Page } & \text { i }\end{array}$

$\begin{array}{ll}\text { Abstract } & \text { ii }\end{array}$

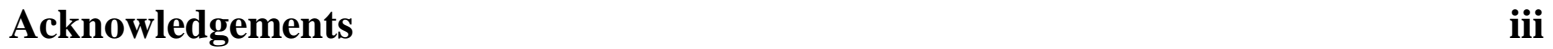

Table of Contents $\quad$ iv

$\begin{array}{ll}\text { List of Tables } & \mathbf{v}\end{array}$

$\begin{array}{lll}\text { List of Figures } & \text { vi }\end{array}$

Chapter One: Nucleic Acid Degradation as a Mechanism for Estimating the Age of Semen Stains in Forensic Casework

Introduction

Materials \& Methods $\quad$ 6-12

Results

17-18

Discussion

Chapter Two: The Eradication of DNA Contamination from RNA Isolates Introduction

34-35

Methods and Materials

36-44

Results

45-46

Discussion

56-57

References

58-60 


\section{List of Tables}

1-1. Real-time PCR primers and probes designed using Applied Biosystems' Primer Express ${ }^{\circledR}$ Software Version 3.0 and the sizes of the amplified products

1-2. Optimized primer sets with their respective real-time PCR parameters

2-1. Loss of cDNA following various DNase treatments 


\section{List of Figures}

1-1. Example Primer and Probe Design for PRM2 mRNA specificity 15

1-2. Optimization of multiplexed primer sets using control sperm cDNA \& DNA $\quad 16$

1-3. Average SRY degradation in dried semen stains at room temperature over time 19

1-4. Average SRY degradation in dried semen stains at $35^{\circ} \mathrm{C}$ over time 20

1-5. Average SRY levels in dried semen stains at room temperature over time 21

1-6: Real-time data showing Average PRM degradation in dried semen stains 22

1-7. Average PRM degradation in dried semen stains at room temperature over time 23

1-8. Average PRM degradation in dried semen stains at $35^{\circ} \mathrm{C}$ over time 24

1-9. Average PRM levels in dried semen stains at room temperature over time $\mathbf{2 5}$

1-10. Average PRM degradation in condoms left at room temperature over time 26

1-11. Average PRM levels in condoms left at room temperature over time 27

1-12. Average initial PRM levels detected in dried semen stains $\quad \mathbf{2 8}$

2-1. Average DNA \& RNA levels isolated from porcine tooth pulp using various Tri-reagent ${ }^{\circledR}$ protocols.

2-2. Average DNA \& RNA levels isolated from porcine tooth pulp using various isolation techniques

2-3. DNA contamination present after various isolation protocols prior to DNase Treatments

2-4. Average GapNT-201 DNA contamination present in semen stains before and after various DNase treatments

2-5. Average loss of blood $\mathrm{Ba} 4$ cDNA after various DNase treatments

2-6. Average loss of semen PRM1 cDNA after various DNase treatments

2-7. Average loss of porcine tooth pulp PBA-71 cDNA after various DNase Treatments

2-8. Average loss of cDNA following various DNase Treatments 
Chapter One: Nucleic Acid Degradation as a Mechanism for Estimating the Age of Semen Stains in Forensic Casework 


\section{Introduction}

During the commission of an assault, evidence is deposited through interactions between perpetrator and victim. Oftentimes it is difficult to determine if biological evidence containing Deoxyribonucleic Acid (DNA) found at the scene was left during the execution of the crime or deposited during a previous interaction. Through Short Tandem Repeat (STR) analysis, the person from whom the sample originated is often easily determined; however, to link or exclude the source from the commission of the crime requires witness testimony or other evidence. When this is lacking, it may lead to the challenge in court as to the value of the obtained genetic profile. It may be argued that the DNA sample was left prior to the commission of the crime due to a personal relationship between the suspect and victim. When the victim and suspect had a history of previous personal contacts, it is not uncommon for the suspect's DNA to end up on or around the victim and vice versa. Being able to distinguish when a biological sample was deposited would help to resolve this dilemma. Because Ribonucleic Acid (RNA) is found in greater amounts per cell and is more labile than DNA, therefore degrading at a faster rate [1], it has been used to estimate the ex vivo age of biological specimens [2;3].

The field of forensic science research has grown substantially in the last few years. RNA has become a widely studied biological molecule for the use in evidence analysis and forensic science investigations. RNA has recently been studied to estimate the post mortem interval (PMI) or time since death of a victim [4;5], to establish the type of biological stain deposited at a crime scene [6], and more recently to establish the "time of deposit" or age of a biological sample [2;3]. Although RNA does not have distinguishing properties to differentiate between two people, when mixed with STR genotyping, the evidentiary value of RNA grows significantly. The conjunction of the type of stain deposited, the time in which it was deposited, the time of death of the victim, and the DNA profile of the suspect could help to answer the questions: who left the biological stain and when? Not only would this strengthen evidence in the court of law, but it may also help to exclude non-relevant biological specimens, allowing the police to focus their efforts on other, more promising leads.

Although all cells contain the same genetic material in the form of DNA, messenger RNA (mRNA) is often transcribed only at specific times or in specific cells. Therefore it is possible to identify the type of biological stain present at a crime scene by analyzing the types of mRNA expressed. With the development of quantitative real-time reverse transcription 
polymerase chain reaction (qRT-PCR), confirming the type of stain is both reliable and relatively simple [7; 8]. In qRT-PCR, labile RNA is first converted to stable, complementary DNA (cDNA); a target sequence is then amplified and quantified with the use of sequence specific primers and probes. Identifying the relative age of bloodstains by analyzing the degradation rates of varying types of housekeeping RNAs using qRT-PCR has been explored [2]. It was determined that $18 \mathrm{~S}$ ribosomal RNA (rRNA) is relatively stabile, most likely because it is protected by tight associations with ribosomal proteins, whereas $\beta$-actin mRNA degrades in a more rapid, predictable fashion. Therefore, by analyzing the $18 \mathrm{~S} / \beta$-actin ratio one could estimate a time over which the bloodstain could have been deposited [2]. Although currently this technique only provides a range of deposition times, that estimation could have significant implications for supporting or refuting a suspect's alibi.

It was later determined that for highly degraded biological samples, the amount of detection using qPCR was directly correlated to the size of the target. It was found that for highly degraded samples, a smaller sequence was detected more often than a larger sequence [9]. This technique was further validated when the degradation of mRNA segments of varying lengths in bloodstains was analyzed [3]. It was hypothesized that if the factors responsible for loss of RNAderived signal acted in a random, stochastic fashion, larger segments will be more susceptible to degradation. This will cause the larger segments to degrade more rapidly and therefore amplification through PCR will be significantly reduced over time. They found that larger segments did indeed degrade at a faster rate than smaller segments [3]. Although currently the way by which mRNA degrades is unclear, nucleic acid degradation rates may be affected by a variety of environmental factors including: humidity, temperature, UV light, $\mathrm{pH}$, generation of free radicals, and the presence of micro-organisms. The time for which samples are exposed to these environmental factors will also affect the degradation rates of the nucleic acids [10]. Once samples are dried, water is no longer available which will greatly reduce/eliminate enzyme activity; however, nucleic acids continue to degrade. Furthermore, oxidative damage of RNA and DNA in dried biological stains has been observed which could lead to the degradation patterns witnessed [11].

In sexual crimes, semen is often left at the scene and there is a need to determine a linkage between the time of ejaculation and the commission of the crime. This is especially important in situations in which the victim and suspect have a known sexual history. When a 
murder has been committed or no witnesses are available, this determination of time since deposit may be critical in the formation of an accurate suspect list. Using similar techniques established for bloodstains, the age of semen stains could be studied [3]. This would allow investigators to establish a temporal linkage between the sex act and the commission of a crime.

Two possible approaches in estimating a time since deposit of semen samples both rely on the differential decay rates of male specific target molecules of varying lengths. One approach looks at the differential decay rates of male specific mRNA's while the other relies on a DNA region found on the Y chromosome. The nucleic acids of interest here are the mRNA's of Protamines 1 and 2 (PRM1 \& 2) and DNA from the Sex Determining Region Y (SRY) gene. Here $18 \mathrm{~S}$ and $\beta$-actin genes will not be useful because they are found in both males and females and therefore will not allow differentiation of samples where a male/female mixture is present.

Sperm cells are unique in that they must contain the same genetic material as other cells but in a much smaller package. Normally, DNA is coiled around an octomer of histones which allows for the formation of chromatin. During the late stages of spermatogenesis histones are first replaced by transition proteins which disrupt the nucleo-histone organization and help to ensure the correct packaging of the sperm nucleus [12]. Transition proteins are then replaced by Protamines (PRMs) [13]. PRMs are arginine and cysteine rich nuclear proteins that help to neutralize the charge found on the DNA molecule thus allowing it to become more compact and stabile. This high level of compaction in mature spermatozoa prevents further transcription and translation of the genome [14]. Expression of the PRMs only occurs in males during spermatogenesis where the ratio of PRM1 to PRM2 is approximately 1:1 [15]. PRM expression has been found to be tightly regulated because protein repressors bind to the mRNA sequences, preventing premature translation [16]. Using in-situ hybridization and RT-PCR, it has been found that PRM1 and PRM2 transcripts are present in mature spermatozoa [14; 17], perhaps due to an over expression of the genome or due to protein protection of the transcript [18]. Due to the necessity of PRMs in sperm cells, and the lack of PRM expression in other male or female cells, PRM mRNA becomes a possible candidate for identifying and analyzing time of deposit of semen stains.

In placental mammals, sex is determined by the presence or absence of the $\mathrm{Y}$ chromosome. Forensic studies often utilize the Y chromosome in determining patrilineal relationships [19]. The genetic information carried on the Y chromosome is passed from father 
to son, analogously to the way that mitochondria are passed from mother to offspring. More than 95\% of the Y chromosome is male specific which makes primer selection for PCR relatively simple [20]. One gene linked to the non-recombining region of the Y chromosome is the SRY gene. SRY is a single copy, intronless gene that encodes for a 204 amino acid protein known as the Testis-Determining Factor (TDF). The TDF protein is responsible for initiating testis differentiation. TDF binds in a sequence specific manner in the minor groove of DNA to induce bending of the DNA molecule stimulating male-specific gene expression [21].

Due to the male specificity of the PRM mRNA and SRY DNA, it may be possible to amplify and quantify only the male sample from a female/male mixture, commonly found in sexual crimes, using qPCR. qPCR allows for the amplification of a specific sequence of interest even when there are only a few copies of the target sequence available; often the situation for forensic casework. By using a technique that co-isolates and amplifies RNA and DNA simultaneously smaller amounts of the precious sample can be used. Using qRT-PCR, determining a time of deposit for semen stains left near a victim and determining if a crime was in fact committed may be possible. 


\title{
Materials \& Methods
}

\author{
Gene Selection
}

Genes located on the Y chromosome or expressed only during spermatogenesis were selected. Gene sequences were obtained from the National Center for Biotechnology Information (NCBI) and verified using the University of California Santa Cruz's Genome Browser. The genes Homo sapiens Protamine 1 (PRM1) (NCBI Reference \#: NM_002761.2), Homo sapiens Protamine 2 (PRM2) (NCBI Reference\#: NM_002762.2) and Homo sapiens Sex Determining Region Y (SRY) (NCBI Reference \#: NM_003140.1) were selected. PRM1 and PRM2 are located on chromosome 16 but the mRNA is expressed only in male sperm, while SRY is located on the Y chromosome.

\section{Primer \& Probe Design}

All primers and probes were designed using Applied Biosystems Primer Express ${ }^{\circledR}$ Software Version 3.0 and the sequences can be found in Table 1-1. TaqMan ${ }^{\circledR}$ probes were designed so that the following parameters specified by the software were met: probe length between $13-30$ bases, $\mathrm{Tm}$ between $68-70^{\circ} \mathrm{C}, \% \mathrm{GC}$ between $30-80 \%$, and 5 ' end not a G residue. The following were also avoided: runs of identical nucleotides, 6 consecutive A residues, and a $\mathrm{G}$ in the second position on the $5^{\prime}$ end of $\mathrm{Fam}^{\mathrm{TM}}$ dye-labeled probes. All probes utilized the quencher Tamra ${ }^{\mathrm{TM}}$ and either the fluoroscene $\mathrm{Fam}^{\mathrm{TM}}$ or Vic ${ }^{\mathrm{TM}}$. Primers were designed using the following parameters specified by the software: primer length around 20bp, Tm between 58$60^{\circ} \mathrm{C}$, and $\% \mathrm{GC}$ between $30-80 \%$. The following were also avoided: runs of identical nucleotides and 3' end containing no more than two $\mathrm{G}$ and $\mathrm{C}$ residues.

Two primer pairs were designed for the SRY gene specifically in the coding region of the TDF protein. This region is expected to be highly conserved, containing fewer polymorphisms. The primer pairs designed allow for the amplification of male DNA amplicons 87bp and 300bp in length. Amplicons are segments of cDNA or DNA that can be amplified using the PCR amplification technique.

PRM primer and probe combinations were designed to be RNA specific by containing either a primer or probe that spans an exon-exon boundary (Figure 1-1). Spanning an exon-exon boundary allows for mRNA rather than contaminating DNA to be amplified. The primer pair 
designed for PRM1 allow for the amplification of a cDNA amplicon 72bp in length. The primer pairs designed for PRM2 allow for the amplification of cDNA amplicons 77bp, 198bp and 310bp in length. All primers and probes were checked for specificity and amplicon size using NCBI's Primer-Blast.

Previously designed glyceraldehyde 3-phosphate dehydrogenase (GAPDH) primers were used to detect DNA contamination present in our samples. GAPDH amplifies a DNA amplicon $210 \mathrm{bp}$ in length.

\section{Primer Optimization}

All primer pairs were multiplexed into sets, therefore optimization was crucial to ensure that any differences in Cycle Threshold $(\mathrm{Ct})$ values obtained from qPCR were due to degradation of the sample and not a difference in primer efficiency. Primer sets were optimized using varying primer concentrations and qPCR parameters (Table 1-2). The concentrations of the forward primer matched that of the reverse primer for each primer pair. Relative serial dilutions of control sperm cDNA and DNA were then used to check the efficiency of the primer sets. The log relative dilution was plotted against the average Fam $^{\mathrm{TM}} \mathrm{Ct}$ minus $\mathrm{Vic}^{\mathrm{TM}} \mathrm{Ct}$ values determined by analysis of qPCR. A linear best fit line was included and optimization was determined when the slope of the best fit line was between +/- 0.1 ([Figure 1-2)] [22].

\section{Primer Specificity}

To ensure the primer sets were amplifying the correct sized DNA or cDNA amplicons, PCR was run with optimized primer sets for 40 cycles. Male specificity of the SRY primer set was determined by performing qPCR on both male and female control DNA. Male sperm cDNA specificity of PRM primer sets was determined by performing qPCR on control male DNA and cDNA. PCR products were then run for 3 hrs on a $2.5 \%$ agarose gel containing $0.025 \mathrm{mg}$ ethidium bromide. Bands were visualized using an Alpha Innotech FluorChem ${ }^{\text {TM }}$ SP transilluminator and sized by comparing to the New England Biolabs Quick-Load® 100bp DNA ladder. It was determined that all primer sets amplified the correct amplicons (data not shown). 


\section{Sample collection and storage}

Fresh semen samples were obtained from healthy, non-vasectomized male volunteers of European descent between the ages of 20-25. Samples were collected in a Trojan ${ }^{\circledR}$ condom or in a $50 \mathrm{~mL}$ centrifugation tube, both of which were provided by the laboratory to the donors. Multiple semen samples were obtained from the same donors to determine the variability within individuals. Condoms were placed in an open, $50 \mathrm{~mL}$ centrifugation tube so that the condom folded on itself to prevent contamination but allow for the semen to remain aqueous. The condom was then placed at room temperature with ambient humidity. Samples obtained in a $50 \mathrm{~mL}$ centrifugation tube were briefly vortexed and deposited on white, cotton cloth in $10 \mu \mathrm{L}$ spots. The spots were then allowed to dry. The cloth was then cut in half and placed at either room temperature with ambient humidity or in a Van Waters and Rogers (VWR) International Incubator (Model \# 900L) at $35^{\circ} \mathrm{C}$ with ambient humidity. The samples were removed from the incubator once they reached the desired ages and 3 spots were randomly selected from each of the temperatures, along with liquid samples from the condom. The days selected varied between DNA and RNA studies. Midway through the study the incubator malfunctioned due to a power outage. All samples stored in the incubator were discarded and analysis using the samples stored at room temperature was continued. The protocol was approved by the West Virginia University Institutional Review Board for the Protection of Human Research Subjects (IRB \# 15833).

\section{RNA Isolation}

Aged semen samples were removed from the $35^{\circ} \mathrm{C}$ incubator or from room temperature for processing. RNA and DNA were co-isolated using an organic extraction method. Ten microliters of dried or liquid semen samples were placed in $1.5 \mathrm{~mL}$ eppendorf tubes containing $400 \mu \mathrm{L}$ digest buffer (0.01M Tris- $\mathrm{HCl} \mathrm{pH} 7.5,0.01 \mathrm{M}$ EDTA, $0.05 \mathrm{M} \mathrm{NaCl}$, and $2 \%$ SDS). Twelve microliters of $10 \mathrm{mg} / \mathrm{mL}$ Proteinase K and $16 \mu \mathrm{L} 1 \mathrm{M}$ Dithiothreitol (DTT) were added to lyse the sperm cells, disrupt the disulfide bonds, and hydrolyze the stabilizing membrane proteins found in the sperm cells. The tubes were placed in a $56^{\circ} \mathrm{C}$ water bath for $2 \mathrm{hrs}$. After $2 \mathrm{hrs}$ the tubes were pulse centrifuged using a Beckman Coulter Allegra ${ }^{\mathrm{TM}}$ 25R Centrifuge and 500 $\mu \mathrm{L}$ of Ambion 25:24:1 Phenyl-Chloroform-Isoamyl alcohol (PCI) pH 6.8 was added. The tubes were then vortexed for $15 \mathrm{secs}$ and centrifuged for $10 \mathrm{mins}$ at $16,000 \mathrm{~g}, 4^{\circ} \mathrm{C}$. After centrifugation the upper, aqueous layer was removed and added to a new tube containing $500 \mu \mathrm{L}$ 
PCI. The samples were again vortexed and centrifuged. The aqueous layer containing the nucleic acids was carefully removed and placed in a new $1.5 \mathrm{~mL}$ tube. Sixteen microliters of $5 \mathrm{M}$ $\mathrm{NaCl}$ was added along with $1 \mathrm{~mL}$ of $95 \%$ Ethanol. The samples were then placed at $-80^{\circ} \mathrm{C}$ for $1 \mathrm{hr}$. After $1 \mathrm{hr}$ the samples were centrifuged at $16,000 \mathrm{~g}, 4^{\circ} \mathrm{C}$ for $20 \mathrm{mins}$. The supernatant was then discarded and $500 \mu \mathrm{L}$ of $70 \%$ Ethanol was added. The tubes were briefly vortexed and centrifuged for 10mins. This was repeated one additional time. The supernatant was removed and the samples were allowed to air dry for 10 mins under a fume hood. Forty microliters of nuclease-free water was then added to the samples and they were placed at $56^{\circ} \mathrm{C}$ for $10 \mathrm{mins}$ for re-suspension. After re-suspension the samples were pulse centrifuged and placed on ice for qRT-PCR. Samples not reverse transcribed were placed at $-80^{\circ} \mathrm{C}$ until qPCR.

\section{Reverse Transcription}

Total RNA was converted to cDNA using qRT-PCR. In step one of this two-step method, the enzyme reverse transcriptase is utilized, which converts isolated total RNA into one copy of single stranded cDNA using RT-PCR. In step-two, the single stranded cDNA is converted to double stranded cDNA, amplified and quantified using qPCR. Applied Biosystem's TaqMan® Gold RT-PCR Kit was used for all reverse transcription reactions. In order to transcribe total RNA, random hexamer primers were used which utilize all possible combinations of 6 nucleotides. A reverse transcription master mix was made containing final concentrations: 1X TaqMan ${ }^{\circledR}$ RT Buffer, $5.5 \mathrm{mM}$ magnesium chloride, $500 \mu \mathrm{M}$ each dATP, dCTP, dGTP, and dTTP, and $2.5 \mu \mathrm{M}$ random hexamers. Fifty-seven microliters of the master mix was aliqouted into individual PCR tubes and stored at $-20^{\circ} \mathrm{C}$. Each reverse transcription reaction consisted of $57 \mu \mathrm{L}$ master mix, $2.0 \mu \mathrm{L}$ RNase inhibitor $(0.8 \mathrm{U}), 2.5 \mu \mathrm{L}$ multiscribe reverse transcriptase (3.75U), and $38.5 \mu \mathrm{L}$ RNA suspension for a total of $100 \mu \mathrm{L}$. Each $100 \mu \mathrm{L}$ reaction can convert a maximum of $2 \mu \mathrm{g}$ of total RNA to cDNA [23].

Reverse transcription samples were pulse vortexed and centrifuged. The samples were then placed in a Techne Touchgene Gradient Thermocycler and converted to single stranded cDNA using one cycle under the following conditions: $25^{\circ} \mathrm{C}$ for $10 \mathrm{mins}$ to anneal random hexamer primers, $48^{\circ} \mathrm{C}$ for $30 \mathrm{mins}$ to extend the primers, $90^{\circ} \mathrm{C}$ for $5 \mathrm{mins}$ to eliminate contaminating RNA, and $4^{\circ} \mathrm{C}$ final hold. Samples were then stored at $-80^{\circ} \mathrm{C}$ until amplified using qPCR. 


\section{Real-Time Polymerase Chain Reaction}

Single stranded cDNA was then converted to double stranded cDNA, amplified, and quantified using qPCR. qPCR is a technique that allows the analyst to not only amplify a target sequence, but also allows the user to monitor the progress of the PCR reaction as the amplification occurs [24]. This technique is very sensitive, straightforward, allows for automation, and is time and labor saving [9]. Our laboratory uses the Applied Biosystems 7300 Real-Time PCR System to amplify and detect fluorescence of our target sequence. The qPCR chemistry relies on the 5' nuclease activity of the AmpliTaq Gold ${ }^{\circledR}$ DNA polymerase [24]. In order for detection to occur, each primer pair must also have a probe located within the target sequence. The probe is a sequence specific oligonucleotide that contains one "reporter" fluorophore (either Fam ${ }^{\mathrm{TM}}$ or $\mathrm{Vic}^{\mathrm{TM}}$ ) covalently attached to the 5' end of the probe and one "quencher" fluorophore (Tamra ${ }^{\mathrm{TM}}$ ) covalently attached at the 3' end. When these two fluorophores are in close proximity to one another, fluorescence is repressed. During the PCR reaction, AmpliTaq Gold ${ }^{\circledR}$ DNA polymerase begins to amplify the target strand. As the polymerase reaches the bound probe, it begins to cleave the probe which allows the reporter to be released from the quencher. Once they are no longer in close proximity to one another, the reporter is able to fluoresce. As more product is generated, the fluorescence exponentially increases. The PCR cycle in which the probe is detected at levels higher than background noise, indicating template amplification, is called the $\mathrm{Ct}$ value [24]; the lower the $\mathrm{Ct}$ value the more starting material present in the sample. Every change in $\mathrm{Ct}$ value is a $2^{(\Delta \mathrm{Ct})}$ fold difference in concentrations of starting material [25].

By multiplexing the reaction, nucleic acid segments of different sizes can be subjected to identical conditions saving labor, time, and sample. To multiplex, two probes and two primer pairs are combined into one reaction. By utilizing probes with different reporter dyes, data can be collected from each target gene simultaneously. In addition to the reporter and quencher dyes, ROX ${ }^{\mathrm{TM}}$ is also utilized as a passive reference to normalize any variations between wells due to pipetting error or differences in volume [24].

Multiplex reactions were used for the primer sets specified previously. Final concentrations for the qPCR mix for each reaction were: primer and probe concentrations specified for each primer set in Table 1-2, 12.5 $\mu \mathrm{L}$ of Applied Biosystems TaqMan® Universal PCR Master Mix, and nuclease-free water to bring the final volume of the reaction to $20 \mu \mathrm{L}$. Five 
microliters of either DNA or cDNA was added and duplicates were run for each sample. Samples were run in an Applied Biosystems 7300 Real-Time PCR System under the following parameters: 1 cycle at $50^{\circ} \mathrm{C}$ for 2 minutes, 1 cycle at $95^{\circ} \mathrm{C}$ for 10 minutes, and 40 cycles at $95^{\circ} \mathrm{C}$ for 15 seconds followed by qPCR extension parameters previously described for each primer set in Table 1-2. For every real-time run, both positive (sperm cDNA) and negative (nuclease-free water) controls were run.

\section{Data Analysis}

After amplification using qPCR, Ct values were obtained for both large and small amplicons for all primer sets which indicate the relative quantity of nucleic acids present in the samples. The $\mathrm{Ct}$ value was kept constant for all days and was obtained by selecting a region within the log linear phase of the exponential growth above any background noise. Relative quantification analysis of the data was performed using Applied Biosystems Sequence Detection Software Version 1.3. The data was exported into Microsoft Excel where the test statistic $2^{(-\Delta \mathrm{CT})}$ was applied to each data point which compares the $\mathrm{Ct}$ values obtained from the large and

small amplicons [26]. The equation $2^{(-\Delta \mathrm{CT})}$ takes into account the exponential nature of the PCR data. Standard deviation and standard error were calculated for each day and temperature. Graphs were made plotting the averages of $2^{(-\Delta \mathrm{CT})}$ over time to examine the differential decay rates of mRNA and DNA segments of various sizes.

\section{Relative Protamine mRNA Quantitation}

In addition to examining the differential decay rates of small and large nucleic acid segments, the relative quantities of the two PRMs were also compared. Ideally, when comparing the differential decay of mRNA segments of different sizes one mRNA is selected from which two primer pairs are designed. One mRNA is selected to ensure that the initial quantity of both large and small segments at Day 0 is equal. Because the PRMs are relatively small, designing two sets of primer pairs that do not overlap and remain RNA specific was not possible. Therefore a primer pair that produces a small amplicon was designed to detect PRM1 and primer pairs that produce larger amplicons were designed to detect PRM2. Because two mRNAs were used in the analyses, initial relative quantities of PRM mRNAs were determined by the $\mathrm{Ct}$ values obtained with the PRM1-72 and PRM2-77 primer set. Because these two amplicons are of 
similar sizes, they should be amplified at approximately the same efficiency and decay at the same rate, thus will determine if the relative quantity of PRM1 and PRM2 are equal or differ between samples. This is necessary because the levels within the semen may differ between or within individuals, thus affecting further analyses. 
Table 1-1: Real-time PCR primers and probes designed using Applied Biosystems' Primer Express ${ }^{\circledR}$ Software Version 3.0 and the sizes of the amplified products

\begin{tabular}{|c|c|c|}
\hline Name & Sequence $\left(5^{\prime} \rightarrow 3^{\prime}\right)$ & Size Amplified (bp) \\
\hline \multicolumn{3}{|l|}{$\begin{array}{l}\text { GAPNT201 } \\
\text { (DNA specific) }\end{array}$} \\
\hline Forward & TGTTTCATCCAAGCGTGTAAG & \multirow{3}{*}{210} \\
\hline Reverse & СССТАСТTТСТССССGCTTT & \\
\hline Probe (VIC) & GTCCTGGGAACCAGCACCGATCAC & \\
\hline \multicolumn{3}{|l|}{$\begin{array}{l}\text { PRM1-72 } \\
\text { (RNA specific) }\end{array}$} \\
\hline Forward & AGGAGAGCCATGAGGTGCTG & \multirow{3}{*}{72} \\
\hline Reverse & TGCTATTTTGTGCAATTAGTGTCTTCT & \\
\hline Probe (VIC) & CGCCCCAGGTACAGACCGCG & \\
\hline \multicolumn{3}{|l|}{$\begin{array}{l}\text { PRM2-77 } \\
\text { (RNA specific) }\end{array}$} \\
\hline Forward & CTTAGTGCCTTCTGCATGTTCTCTT & \multirow{3}{*}{77} \\
\hline Reverse & AAGACGCTCCTGCAGGCA & \\
\hline Probe (FAM) & CTGGTTCTGCAGCCTCTGCGATGC & \\
\hline \multicolumn{3}{|l|}{$\begin{array}{l}\text { PRM2-198 } \\
\text { (RNA specific) }\end{array}$} \\
\hline Forward & CTTAGTGCCTTCTGCATGTTCTCTT & \multirow{3}{*}{198} \\
\hline Reverse & CGGAGCACGTCGAGGTCTAC & \\
\hline Probe (FAM) & CTGGTTCTGCAGCCTCTGCGATGC & \\
\hline \multicolumn{3}{|l|}{$\begin{array}{l}\text { PRM2-310 } \\
\text { (RNA specific) }\end{array}$} \\
\hline Forward & CTTAGTGCCTTCTGCATGTTCTCTT & \multirow{3}{*}{310} \\
\hline Reverse & ATGGTCCGATACCGCGTG & \\
\hline Probe (FAM) & CTGGTTCTGCAGCCTCTGCGATGC & \\
\hline \multicolumn{3}{|l|}{ SRY-87 } \\
\hline Forward & TTTCGAACTCTGGCACCTTTC & \multirow{3}{*}{87} \\
\hline Reverse & GAATACGCTTAACATAGCAGAAGCAT & \\
\hline Probe (VIC) & TGTCGCACTCTCCTTGTTTTTGACAATGC & \\
\hline \multicolumn{3}{|l|}{ SRY-300 } \\
\hline Forward & TGCACAGAGAGAAATACCCGAAT & \multirow{3}{*}{300} \\
\hline Reverse & CATCTAGGTAGGTCTTTGTAGCCAATG & \\
\hline Probe (FAM) & CGAAGAATTGCAGTTTGCTTCCCGC & \\
\hline
\end{tabular}


Table 1-2: Optimized primer sets with their respective real-time PCR parameters

\begin{tabular}{|c|c|c|c|}
\hline $\begin{array}{c}\text { Optimized Primer } \\
\text { Sets }\end{array}$ & $\begin{array}{c}\text { Optimized Primer } \\
\text { Concentrations } \\
(n m) *\end{array}$ & $\begin{array}{c}\text { Annealing/Extension } \\
\text { Temperatures }\left({ }^{\circ} \mathrm{C}\right)\end{array}$ & $\begin{array}{c}\text { Annealing/Extension } \\
\text { Times (min) }\end{array}$ \\
\hline GAPNT-201 & 900 & 60 & 1.0 \\
\hline $\begin{array}{l}\text { PRM1-72: PRM2-77 } \\
\text { (RNA specific) }\end{array}$ & $150: 250$ & 58 & 1.0 \\
\hline $\begin{array}{l}\text { PRM1-72: PRM2-198 } \\
\text { (RNA specific) }\end{array}$ & $60: 600$ & 58 & 2.5 \\
\hline $\begin{array}{l}\text { PRM1-72: PRM2-310 } \\
\text { (RNA specific) }\end{array}$ & $60: 1200$ & 58 & 2.5 \\
\hline SRY-87: SRY-300 & $150: 1100$ & 60 & 2.5 \\
\hline
\end{tabular}

*All forward and reverse primer concentrations were identical within primer pairs. Probe concentrations were set at $250 \mathrm{~nm}$ for all primer pairs. 


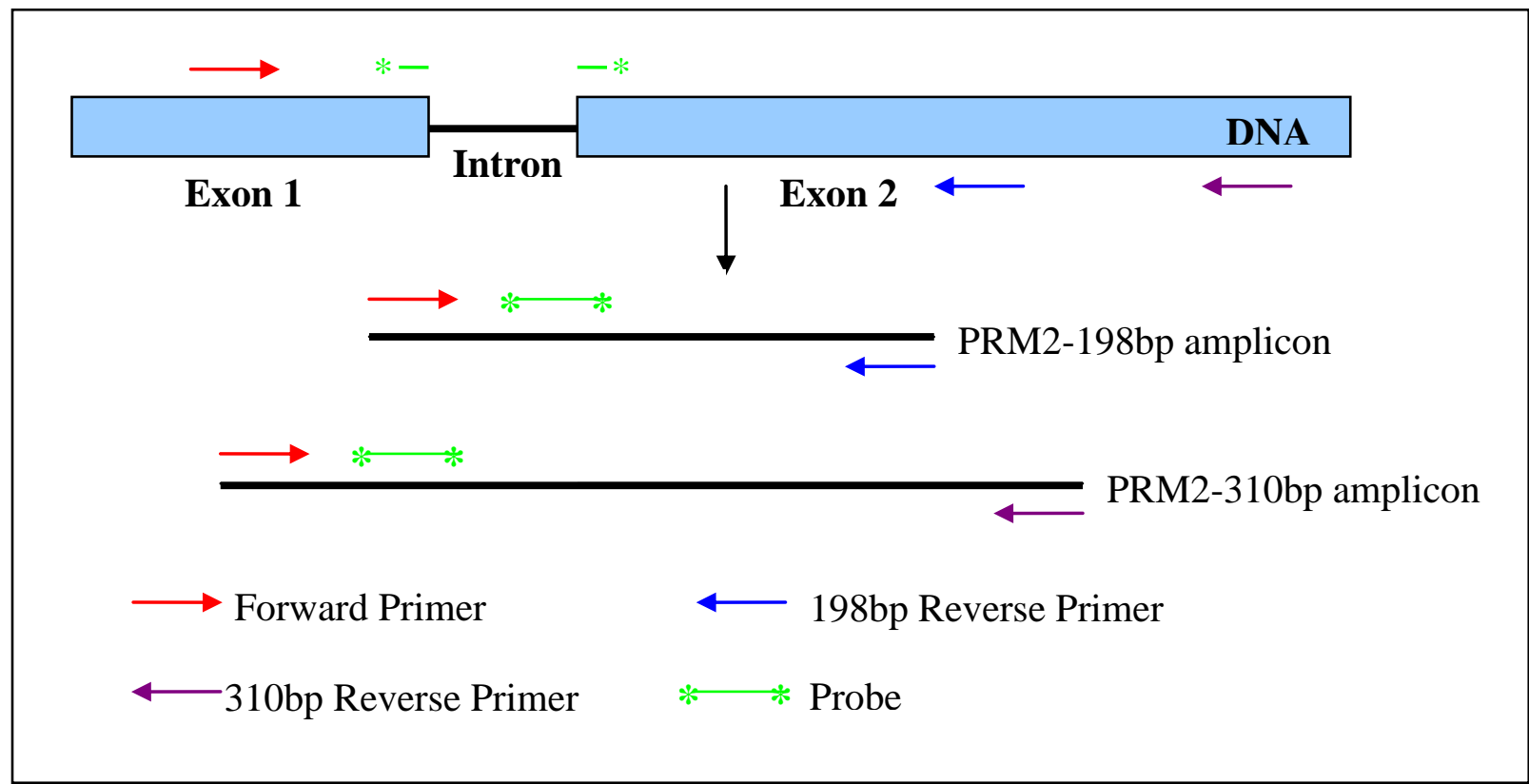

Figure 1-1: Example primer and probe design for PRM2 mRNA specificity. By spanning a probe over an exon-exon boundary, contaminating DNA may be amplified but will not be detected using qPCR. When a primer spans an exon-exon boundary, neither amplification nor detection is possible. 


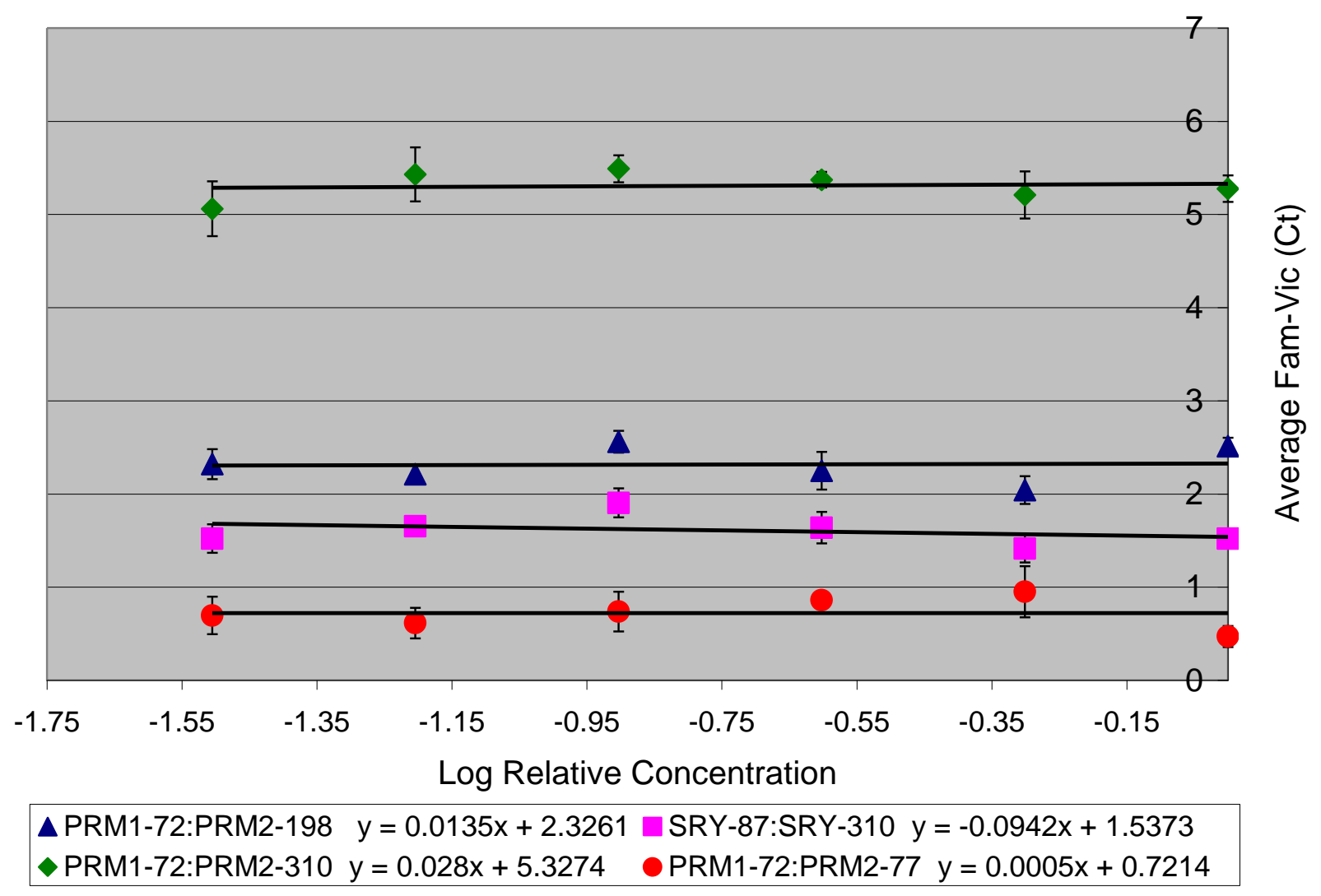

Figure 1-2: Optimization of multiplexed primer sets using control sperm cDNA \& DNA. The primer sets were considered optimized when the slope was between \pm 0.1 . For the above primer sets, PRM1-72 and SRY-87 were Vic ${ }^{\text {TM }}$ labeled whereas PRM2 and SRY-310 were Fam $^{\text {TM }}$ labeled. 


\section{Results}

SRY DNA was found to remain stable over time; the 300bp segment did not degrade more rapidly than the $87 \mathrm{bp}$ segment. A negative correlation between time and $2^{(-\Delta \mathrm{Ct})}$ was not observed for stains left at room temperature or at $35^{\circ} \mathrm{C}$ (See Figures [1-3] \& [-4). There was initial degradation present within the first few days but after day 3 it began to stabilize. The initial degradation observed varied; therefore estimating the age of a semen stain in this time frame will not be reliable. As shown in Figure [1-5, the difference in relative quantity between small and large SRY segments stayed fairly equal as the samples aged; the difference did not increase as was expected if differential degradation was occurring. At room temperature both DNA amplicons were observed until at least day 237 . For stains left at $35^{\circ} \mathrm{C}$, analysis was only performed up until day 22 due to the incubator malfunctioning midway through the study.

Similar results were obtained for PRM mRNA degradation. It was found that PRM mRNA does not degrade in a predictable fashion and remains relatively stable up to day 96 . Over extended periods of time, differential degradation began to occur. In dried semen stains left at room temperature, both RNAs could be detected for all data points tested up to at least day 347. At day 347, PRM1-72 and PRM2-198 were still successfully amplified whereas PRM2310's curves begin to lose their exponential shape (See Figure 1-6 (a)). As seen in Figures 1-7 \& 1-8, an initial degradation was observed between days 1 and 3, but as the semen stains aged the mRNA degraded in an unpredictable fashion. Figure 1-9 shows the relative levels of PRM mRNA over time at room temperature. The difference in relative quantity between PRM1-72 and PRM2-310 segments stayed fairly equal as the samples aged; the difference did not increase as was expected if differential degradation was occurring. This was also observed for PRM1-72 and PRM2-198 levels (data not shown). For stains left at $35^{\circ} \mathrm{C}$, degradation analysis could not be performed after day 45 due to the incubator malfunction previously described. Up to day 45 , temperature did not appear to have an effect on mRNA degradation when the samples were in a dried state. RNA was later isolated from previously dried samples left at $35^{\circ} \mathrm{C}$ to determine the stability of the two RNAs over extended periods of time. At day 554 , the $35^{\circ} \mathrm{C}$ samples showed differential degradation. PRM1-72 was still amplifiable but PRM2-198 began to appear in the region considered background (Ct values greater than 35). PRM2-310 was undetectable at day 554 (See Figure 1-6 (b)) ). Over extended periods of time, extreme temperatures began to drastically reduce the RNA yield. 
When liquid semen was left in a condom most RNA was lost after day 14. In a short time frame, the PRM1-72 remained stable, whereas the PRM2-198 began to degrade (see Figure 110). Although levels of PRM2-310 were detected, the real-time plots began to lose the ideal exponential curvature making analysis less reliable. Eventually PRM2-310 could no longer be detected after 40 cycles. Figure 1-11] shows that the difference in quantity between PRM1-72 and PRM2-198 began to increase after day 3. PRM2-310 levels were no longer reliably detected after day 7 using qPCR with 40 cycles. DNA was obtained from liquid samples up until day 20 but samples degraded in an unpredictable fashion and began to lose the ideal exponential shape of the real-time data (data not shown).

To determine whether the initial levels of PRM1 and PRM2 were equal, a multiplex was performed which amplified a $72 \mathrm{bp}$ and a $77 \mathrm{bp}$ segment simultaneously. Because these segments are similar in size, neither should be preferentially amplified using qPCR. Randomly selected samples, from the same individual, show that different levels of the two mRNAs were observed (see Figure 1-12). The amount of starting mRNA levels differed between and within samples. 


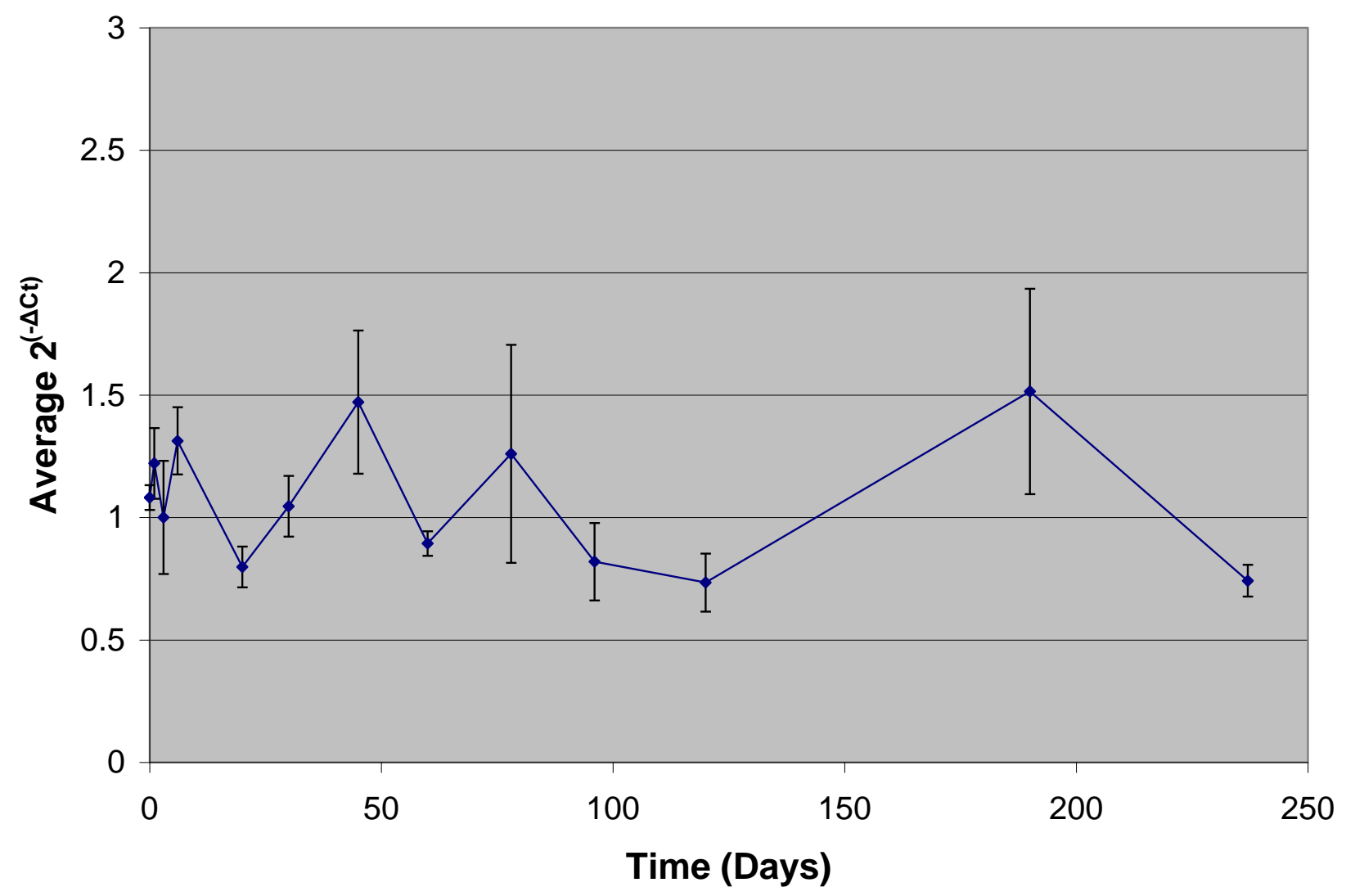

Figure 1-3: Average SRY degradation in dried semen stains at room temperature over time. A negative correlation was not observed as the semen stains aged, indicating that the large and small DNA segments remained stable over time. DNA was still successfully amplified up until at least day 237. 


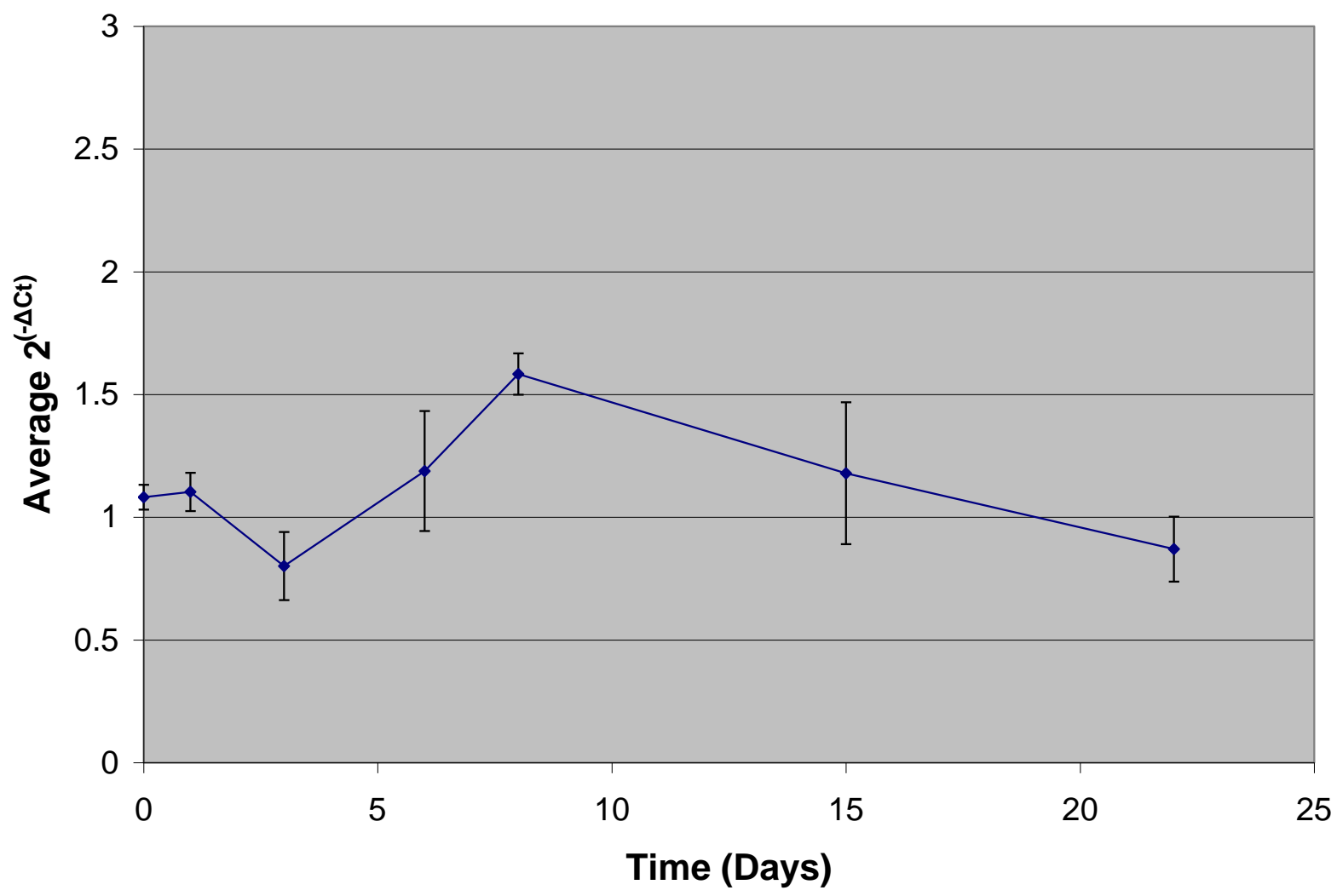

Figure 1-4: Average SRY degradation in dried semen stains at $35^{\circ} \mathrm{C}$ over time. A negative correlation was not observed as the semen stains aged indicating that the large and small DNA segments remained stable over time. The incubator malfunctioned, preventing DNA samples from being analyzed after day 22. 


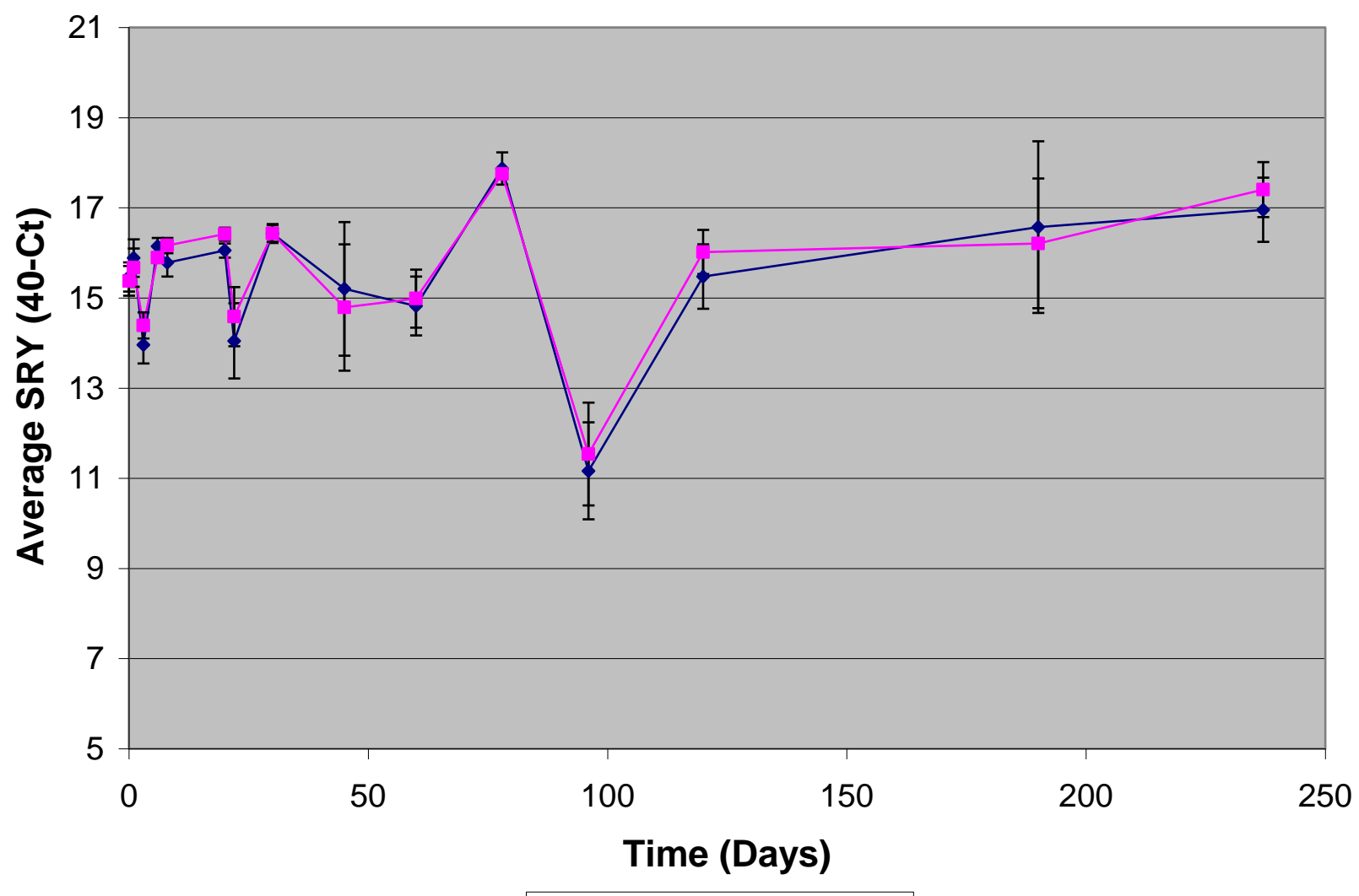

$\rightarrow$ SRY-300 $\rightarrow-$ SRY-87

Figure 1-5: Average SRY levels in dried semen stains at room temperature over time. As the samples aged, the difference between small and large amplicons stayed relatively equal. Forty cycles were run thus 40 minus $\mathrm{Ct}(40-\mathrm{Ct})$ was calculated to indicate the amount of RNA signal obtained. The larger the 40-Ct value, the more sample was isolated. 
(a)

Delta Rn vs Cycle

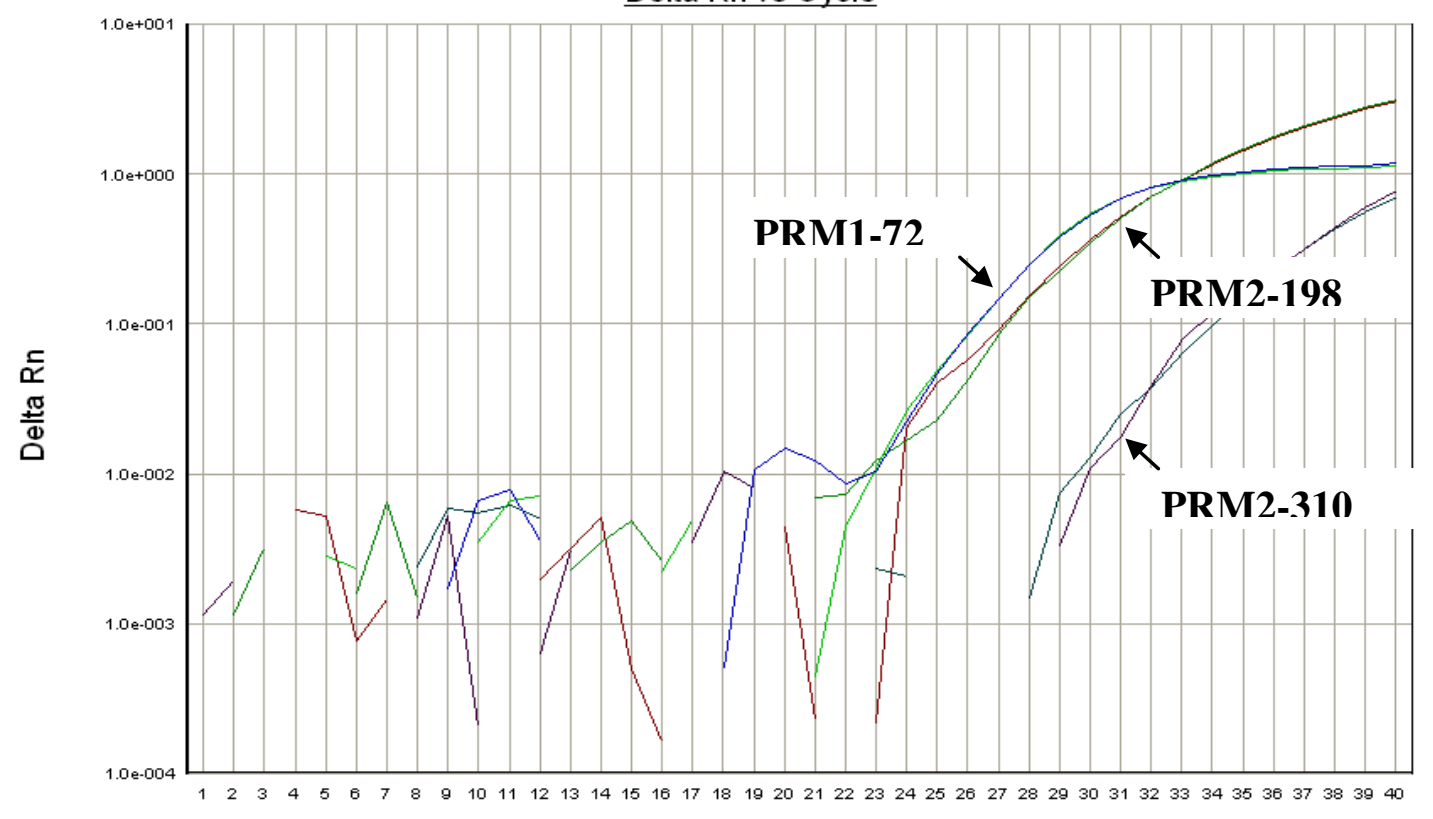

Cycle Number

(b)

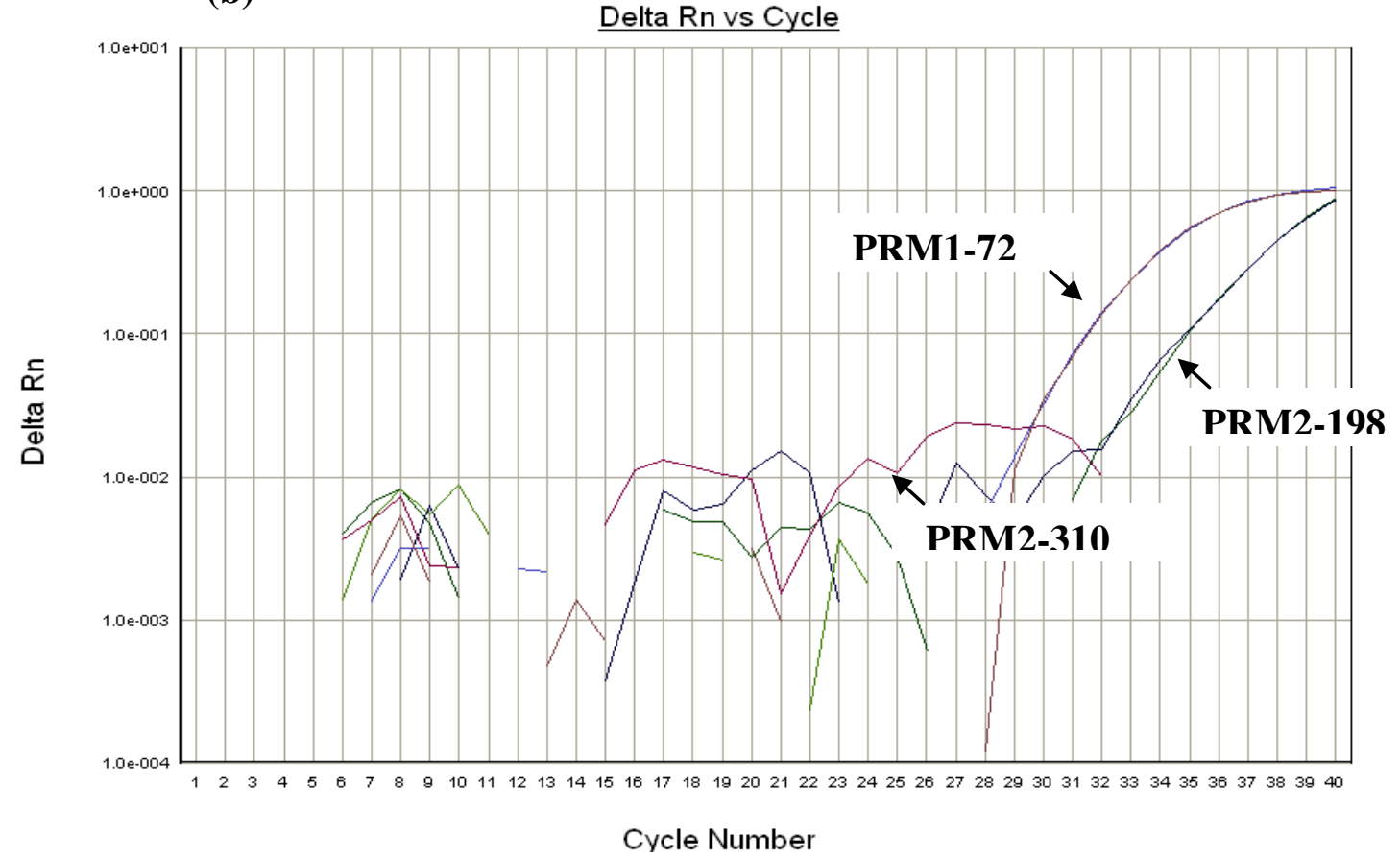

Figure 1-6: Real-time data showing Average PRM degradation in dried semen stains. (a) Day 347 curves of samples left at room temperature. PRM1-72 \& PRM2-198 were still successfully amplified whereas PRM2-310 began to lose its exponential curvature. (b) Day 554 curves of samples left at $35^{\circ} \mathrm{C}$. PRM1-72 was amplifiable, PRM2-198 was approaching limits of reliable detection $(\mathrm{Ct}<35)$, and PRM2-310 was undetected. 


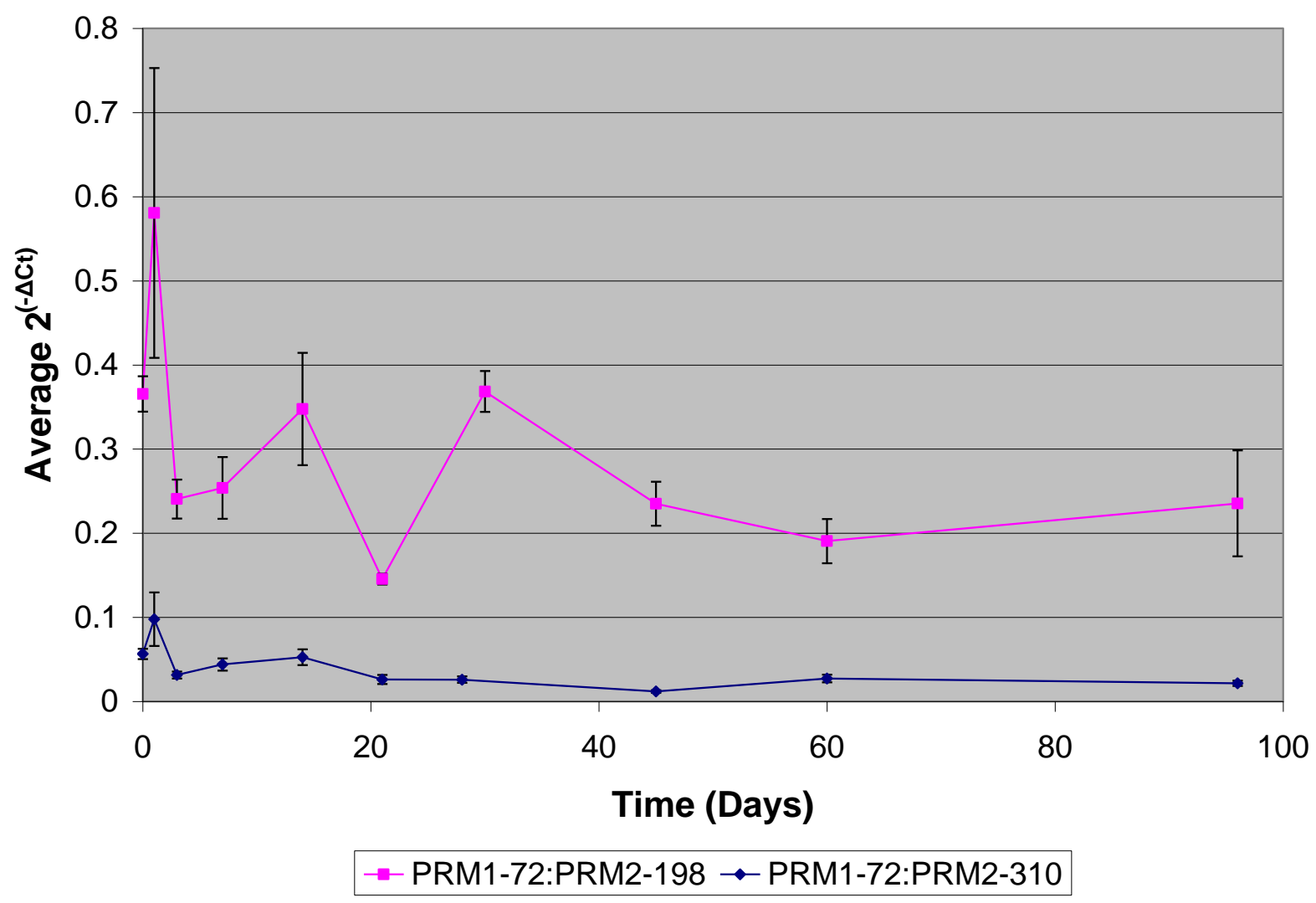

Figure 1-7: Average PRM degradation in dried semen stains at room temperature over time. At day 1 an initial degradation was observed; however as the semen stains aged the mRNA degraded in an unpredictable fashion. 


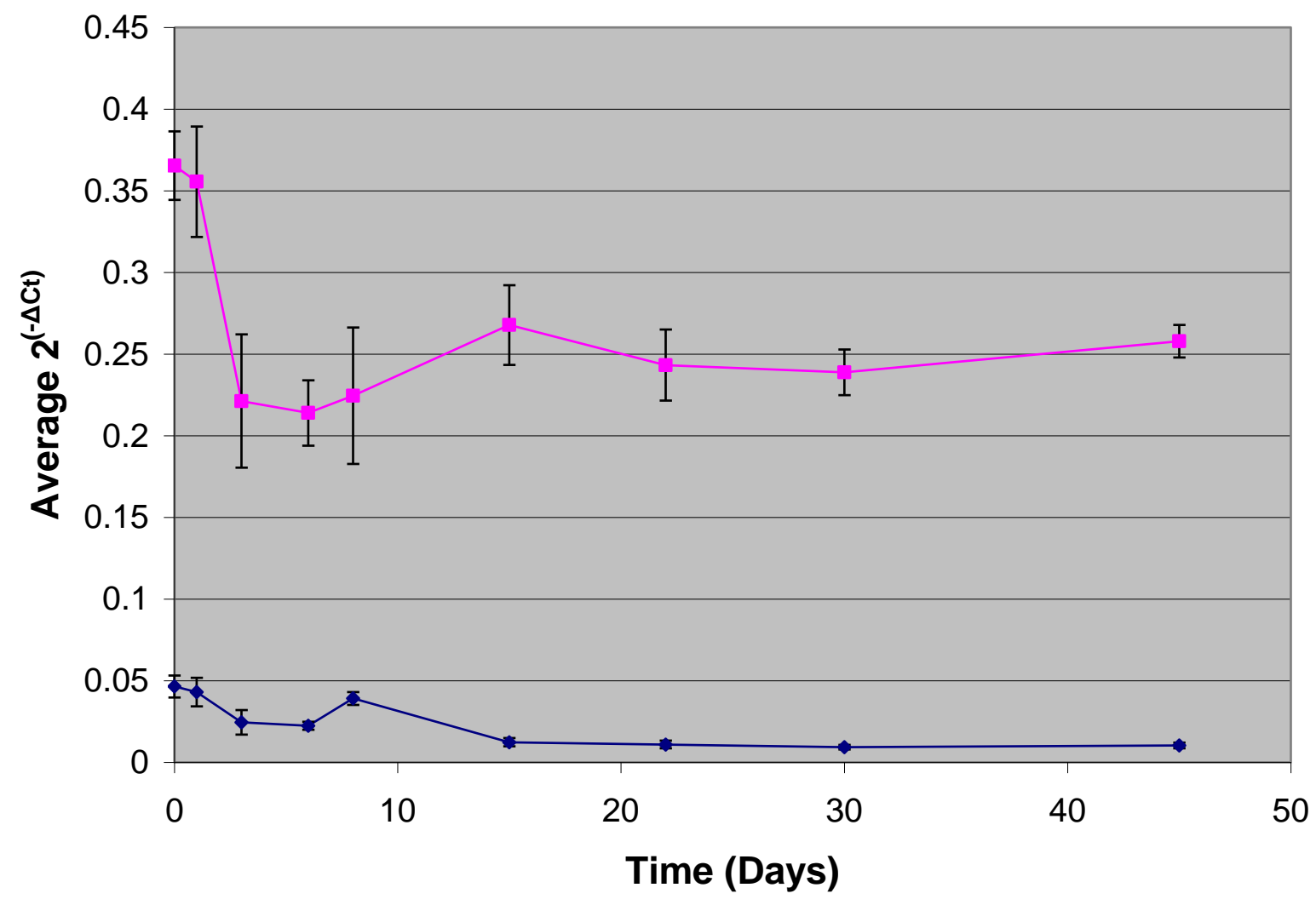

PRM1-72:PRM2-198 - $\rightarrow$ PRM1-72:PRM2-310

Figure 1-8: Average PRM degradation in dried semen stains at $35^{\circ} \mathrm{C}$ over time. At day 1 an initial degradation was observed; however as the semen stains aged the mRNA degraded in an unpredictable fashion. The incubator malfunctioned, preventing mRNA samples from being analyzed after day 45 . 


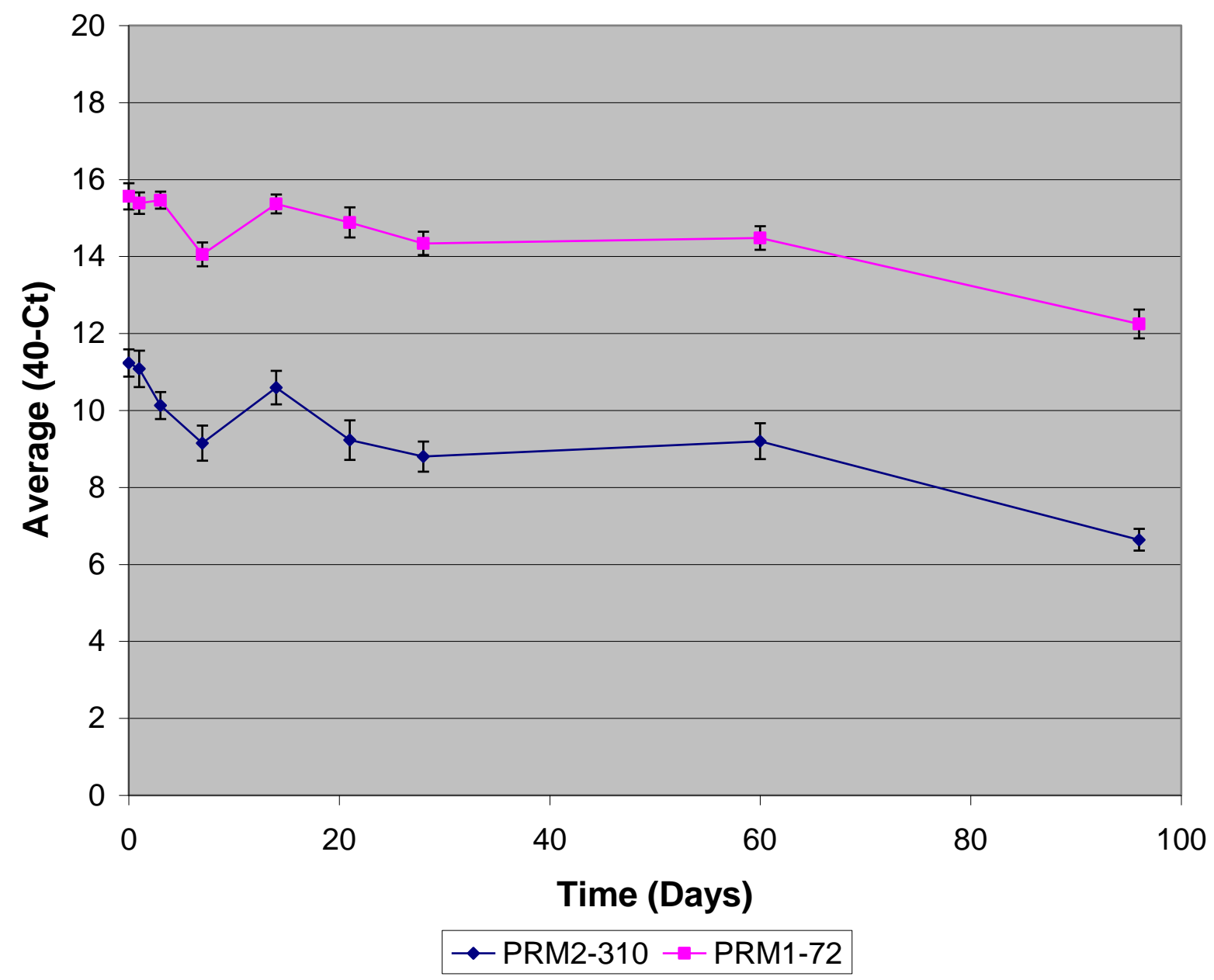

Figure 1-9: Average PRM levels in dried semen stains at room temperature over time. As the samples aged, the difference between small and large amplicons stayed relatively equal. Forty cycles were run thus 40 minus $\mathrm{Ct}(40-\mathrm{Ct})$ was calculated to indicate the amount of RNA signal obtained. The larger the 40-Ct value, the more sample was isolated. 


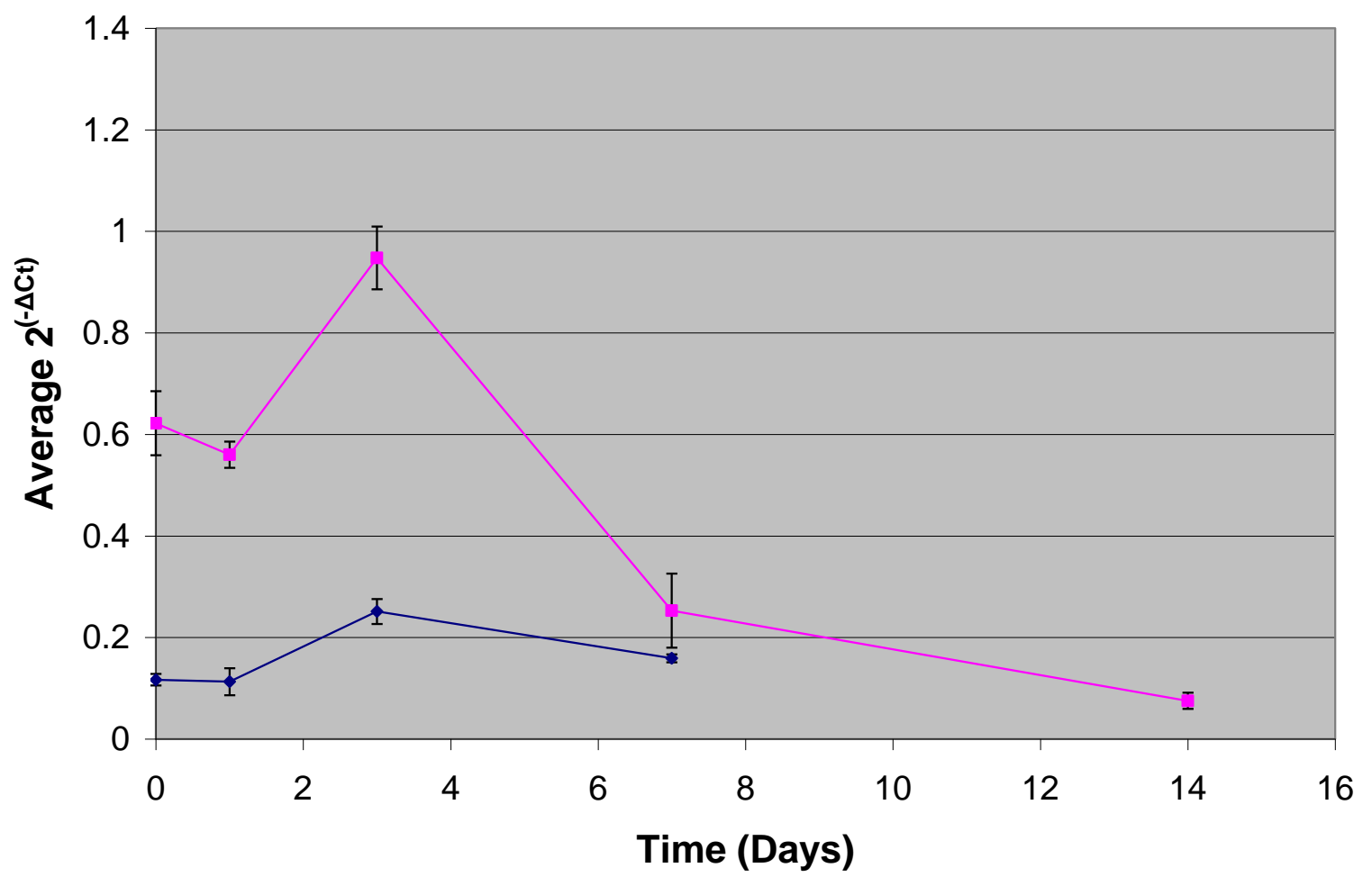

PRM1-72:PRM2-310 - PRM1-72:PRM2-198

Figure 1-10: Average PRM degradation in condoms left at room temperature over time. As the semen aged differential degradation was observed. PRM2-310 signal was undetected after day 7 therefore $2^{(-\Delta \mathrm{Ct})}$ could not be calculated for the PRM1-72:PRM2-310 primer set. A negative correlation was observed for the PRM1-72:PRM2-198 primer set; as the sample aged, $2^{(-\Delta \mathrm{Ct})}$ decreased. 


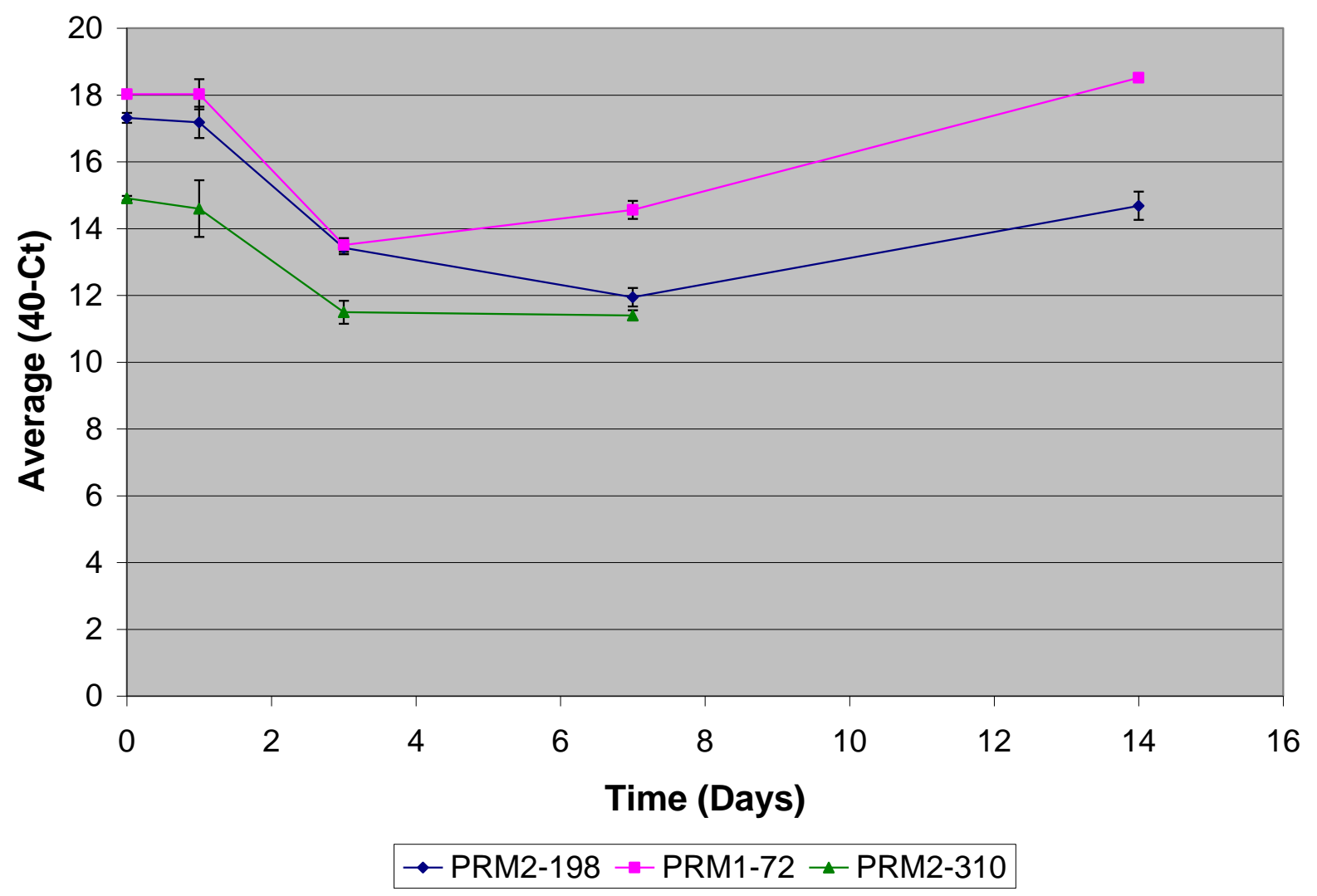

Figure 1-11: Average PRM levels in condoms left at room temperature over time. Forty cycles were run thus 40 minus $\mathrm{Ct}(40-\mathrm{Ct})$ was calculated to indicate the amount of RNA signal obtained. The larger the 40-Ct value, the more sample was detected in qPCR. The levels of PRM1-72 and PRM2-198 remained relatively equal up until day 3. After day 3, an increase in the difference between segments was observed which indicates differential degradation. PRM2310 was no longer detected after day 7. 


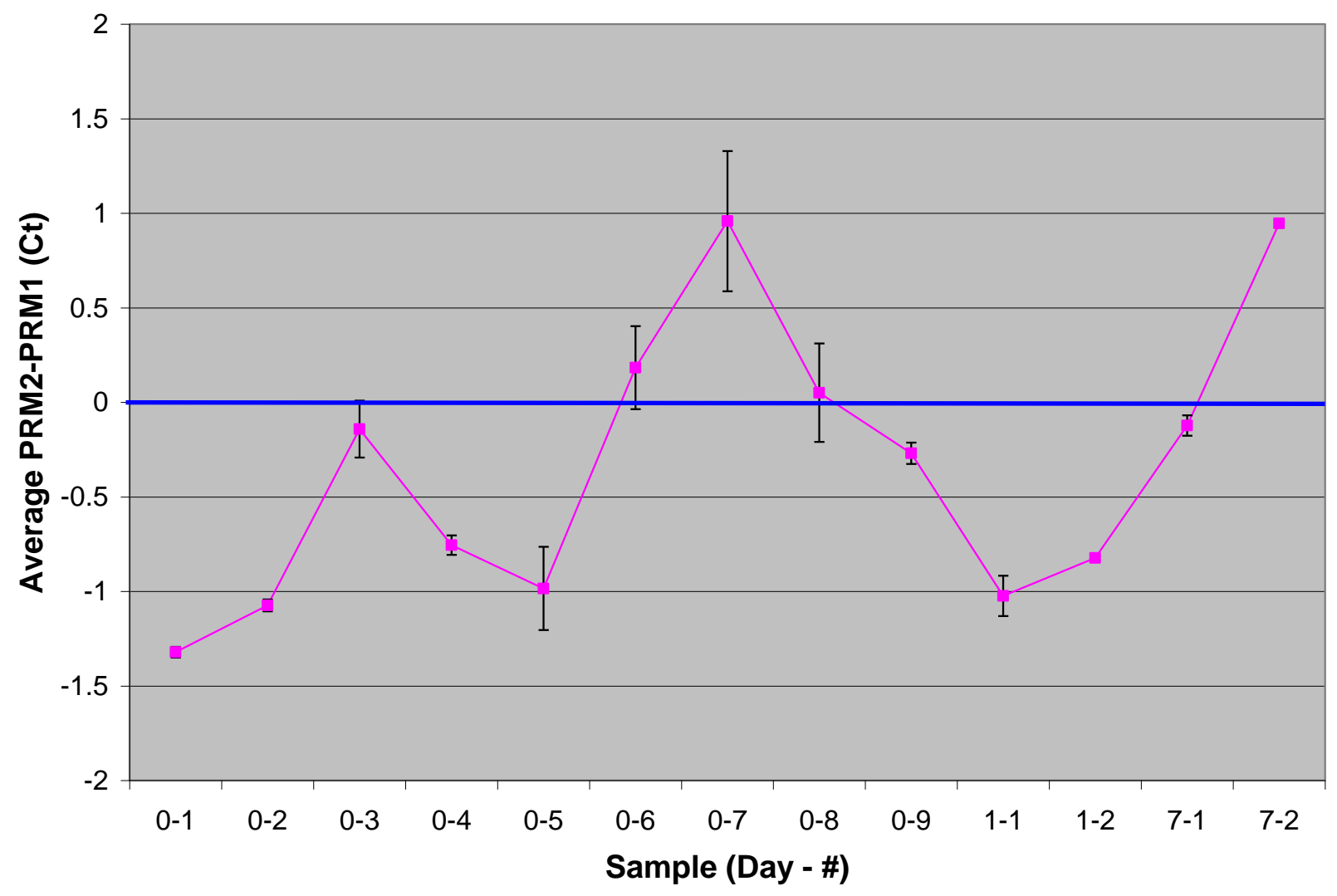

Figure 1-12: Average initial PRM levels detected in dried semen stains. Samples were randomly selected to determine the relative initial quantity of both PRM1 and PRM2 mRNA. PRM2 minus PRM1 values of 0 correspond to equal mRNA levels indicated by the blue line. Negative values indicate that more PRM1 mRNA was observed in the sample, whereas positive values indicate that more PRM2 mRNA was observed in the sample. Every increase in Ct value correlates to a $2^{(\Delta \mathrm{Ct})}$ or a doubling of starting material. 


\section{Discussion}

Linking semen deposition to the commission of an assault relies on the ability of the analyst to estimate when a semen stain was deposited at a crime scene. Unfortunately both SRY and PRM were not useful at predicting the age of dried semen stains. It is not surprising that SRY DNA was found to remain stable over time due to the fact that DNA is known to be less labile than mRNA [1]. Also, DNA is tightly bound to protamine proteins in sperm cells, helping to stabilize the DNA molecule which in turn protects it from degradation. Over time DNA should begin to degrade and it is expected that larger segments of the DNA molecule would decay more rapidly than smaller segments; no difference, however, was observed in samples as old as 237 days. If differential degradation is observed after day 237, it may be possible to exclude the semen stain from a potential assault when comparing the approximate age of the stain to the PMI of the victim. DNA from dried semen stains did show an initial degradation between days 1 and 3; however, due to the unpredictable nature of the decay, estimating the age of a stain would not be reliable within this time frame. Increased enzyme activity or incomplete drying could possibly explain this initial spike. Degradation of DNA from liquid semen was also found to be unpredictable; however over extended periods of time, it may be possible to exclude an aqueous semen sample as evidence if the sample's approximate age is outside the time frame of when a potential assault may have occurred.

In dried semen stains mRNA could be detected for all data points tested; however the degradation remained random. The difference between the relative levels of the small and large segments remained equal over time which indicates that neither are degrading or they are both degrading at approximately the same rate. This does not support the hypothesis that larger fragments would degrade rapidly, whereas small amplicons would remain stable over time. If differential degradation was occurring, $2^{(-\Delta \mathrm{Ct})}$ would have shown a negative correlation with time and the differences between the levels of the two segments should increase over time. Because PRM mRNA does not degrade in a predictable fashion, it becomes an unlikely candidate for estimating the age of dried semen stains. Over extended periods of times and at extreme temperatures, differential degradation was observed which could possibly exclude the semen stain from a potential assault when the approximate age of the stain is compared to the PMI of the victim. For example, if the semen stain was determined to be at least one year old, yet the 
PMI of the victim was determined to be 6 months, the police could exclude the semen stain as a piece of evidence.

When liquid semen was left in a condom most RNA was lost after day 14. It was found that the 72bp PRM1 remained stable, whereas the 198bp PRM2 began to degrade by day 7 . The difference between the relative quantities of the two mRNAs began to increase over time; indicating that differential degradation is in fact occurring. After day 7, the $310 \mathrm{bp}$ segment of PRM2 could no longer be successfully amplified after 40 cycles and the curves were no longer smooth, indicating rapid degradation. Because complete degradation was observed with the large 310bp PRM2 segment after one week, the lack of amplification could indicate how long a condom was present at a crime scene. For instance, if a rape/homicide was committed and a condom found, lack of PRM2-310 amplification could indicate if the condom was related to the crime in question when compared to the PMI. If the PMI was determined to be 3 days, yet no PRM2-310 amplification was observed, the condom may be excluded as a piece of evidence. This does, however, rely on the analyst performing this analysis relatively quickly or the sample must be stored properly so that further degradation does not occur.

Protamine mRNAs are bound by proteins forming a ribonucleoprotein complex until translation occurs. Mature spermatozoa no longer have the ability to transcribe new RNA's due to the tight compaction of the sperm nucleus. Because of this, these mRNAs may begin to degrade once they are no longer needed by the cell prior to ejaculation. Those mRNAs which remain bound by proteins or that are over expressed could potentially get carried over randomly into the mature spermatozoa. When the initial relative quantities of the PRM mRNA's were analyzed it supported the idea that PRMs are retained due to chance. It was found that the amount of starting mRNA levels differed between and within samples from the same individual. In some instances more PRM1 was found and in other instances more PRM2 was found. Because of this, the degradation may appear unpredictable due to the differences in initial levels between and within samples.

Predictable degradation was found when a similar technique was used on dried bloodstains [3]. Sperm are unique in that they are tightly compacted cells with extremely condensed DNA and whose membranes contain high levels of disulfide bonds. High level of compaction could cause an extra level of protection to the materials within the cell. Protection could prevent environmental factors from degrading the internal nucleic acids. Also, protein 
protection of the protamine mRNA, to prevent premature translation, could help maintain the stability of the mRNAs analogously to the way that $18 \mathrm{~S}$ ribosomal rRNA, which is protected heavily by ribosomal proteins, was found to remain stable [2]. Unlike blood cells, sperm mitochondria are present within the tails not within the cell body. Because of this, damage due to mitochondrial breakdown may not occur as easily to the nucleic acids present in sperm heads. Blood also contains high levels of iron and oxygen; semen lacks these features which could mean that free-radical generation may not occur at the same rate in semen as occurs in blood. Studies are currently being done to determine the effects of free-radical generation on nucleic acid stability. If different free-radicals are produced in blood or in different quantities than found in semen, it could explain some of the stability observed. These differences, among others, between blood and sperm cells could explain some of the variation observed between cell types.

Differential degradation analysis of mRNA segments of varying sizes in bloodstains was done using housekeeping genes [3]. Housekeeping genes are continuously expressed; therefore levels should remain stable between and within samples. Because PRM mRNAs are believed to be residual, different levels may be present within and between samples as previously described. Also, men with fertility issues may have different levels of the transcript and this would not be known to the analyst. Potential problems also arise with men who have had vasectomies, those who are aspermatic, and those who are oligospermatic because little to no sperm cells would be present. In these cases, investigators must rely on the presence of epithelial cells to obtain adequate DNA and RNA for further analyses. Housekeeping genes present in epithelial cells would be more reliable for the use in a broad spectrum of suspects, but problems arise due to the fact that these housekeeping genes are not male specific; therefore will be difficult to separate from a female/male mixture often found in sexual crimes. Unless the semen is physically separated from the female component, as with a condom, housekeeping genes would be expressed in both male and female samples, making analysis impossible.

Both DNA and mRNA were found to remain stable overtime. RNA is becoming an increasingly studied molecule for forensic investigations and the stability of RNA may allow for confirmatory tests to be conducted on older samples. Combining confirmatory tests and STR profiling, answers could be made as to what type of stains are present at the scene and who left them. Investigators could then focus their efforts on potential suspects even months after a crime has been committed. Also, because the nucleic acids were found to remain stable for many 
months or years in dried samples, it supports the idea that although rape kits should be processed quickly, there may not be any devastating effects on the samples if they are not. This is important due to the vast amounts of rape kit backlogs present [27]. It was found that smaller mRNA fragments were present longer in the dried stains; therefore researchers should try to minimize the lengths of amplicons to prevent RNA signal loss if using for confirmatory tests. Because nucleic acids degraded quickly in liquid samples, quicker than most evidence would be processed, samples should be obtained and dried prior to packaging to prevent enzyme degradation and nucleic acid loss in the samples.

At this time, this technique will not be useful for linking semen deposition to the commission of an assault, but it may be possible to exclude the stain as evidence when comparing the approximate age of the stain to the PMI of the victim. Designing primer sets which amplify segments present in the same male-specific mRNA molecule may help to alleviate some of the problems observed due to random trapping of the two PRMs within the sperm heads. Also, a more detailed investigation of liquid samples may allow this technique to be used in the future. Analyzing the lack of large PRM fragments may help to corroborate or refute a suspects alibi. The rapid degradation found in aqueous semen stains may provide a range when the sample was deposited and may help to exclude a condom from the assault. In the future, differential decay of mRNA fragments of different sizes may be used not only for dried and liquid stains, but also for samples present within the body cavity. Other biological stains could be investigated using this technique such as saliva, tooth pulp, or urine. It is expected that the use of mRNA for forensic purposes can be expected to increase with advancements in technology. 
Chapter Two: The Eradication of DNA Contamination from RNA Isolates 


\section{Introduction}

The rise of RNA in forensic science research has lead to an increase in the challenges associated with its analysis. Biological stains found at crime scenes are frequently very small, therefore RNA and DNA often must be isolated simultaneously in order to not waste any of the precious samples. Co-isolation allows for an STR profile to be generated from the DNA sample and multiple RNA analyses to be conducted including: PMI [4;5], identification of the type of biological stain deposited [6], and estimation of the age of the biological stain [2;3]. Once the nucleic acids are isolated, they can be divided into two samples. By separating the samples, half can be amplified and analyzed using STR profiling. The other half of the sample can be reversetranscribed and amplified using qRT-PCR. Unfortunately, DNA contamination can create problems with later RNA analyses by giving the impression of an increased RNA concentration [25]. When primer sets that are RNA specific can be designed there is no issue; total RNA can be converted to cDNA, amplified, and quantified for the various analyses. Constructing RNA specific primer pairs often employs the method of designing a primer or probe that spans an exon-exon boundary, thus the contaminating DNA would not include complete binding sites [28]. If a primer spans the boundary, no DNA amplification occurs, which is ideal. If a probe

spans the boundary, amplification of the DNA occurs but it does not fluoresce in qPCR, thus remains undetected by the software. This allows for RNA specificity but does pose an additional problem; it could reduce the efficiency of the amplification if the primers are wasted amplifying unnecessary target [29].

DNA contamination becomes a problem when primers cannot be made mRNA specific, which is often the case when few or no introns are present in the genes or when pseudogenes are found. Although qRT-PCR has become invaluable in research, it is not able to distinguish between cDNA and DNA. Thus, when DNA contamination is present a lower $\mathrm{Ct}$ value is generated and false RNA concentrations are reported [25]. Multiple protocols exist which help rid samples of DNA contamination. The use of DNase is the most often used, along with acid phenol/chloroform extractions, compaction agents which bind DNA [25], column based RNA purification kits, and multiple other kits claiming to provide DNA-free samples [30]. All of these techniques have their strengths and weaknesses. For instance, when the sample volume is limited, many of these methods are not feasible. 
In previous studies, our laboratory has found that Ambion's TURBO DNA-free ${ }^{\mathrm{TM}}$ DNase treatments have a negative effect on RNA yield after qRT-PCR (S. young, personal communication, July 31, 2009). DNase can easily be carried over into RT-PCR which when activated, degrades the resulting cDNA. Currently, the methods that exist to remove DNase treatments often cause a loss of RNA sample as well or are not satisfactory in their removal of the DNase enzyme. This includes acid phenol/chloroform and intense heat inactivation (temperatures greater than $95^{\circ} \mathrm{C}$ ) [31]. Also, when the DNase treatment is not effective, partially degraded DNA samples have the potential to still produce false amplifications [28]. RNA loss and partially degraded DNA could create problems when trying to estimate the age of a biological sample using RNA because it could artificially create degradation, thus skewing the results.

When ample biological sample is present, RNA and DNA can be isolated separately, but depending on the tissue type present new problems may arise. Using Molecular Research Center (MRC) Inc.'s Tri-Reagent® BD, RNA from blood can easily be extracted which lacks DNA contamination. However, our lab has found that extracting DNA-free RNA from other tissue types such as semen and tooth pulp has been more difficult. Therefore, there needs to be a technique that will either isolate pure RNA from a difficult sample or a DNase treatment must be found to rid DNA contamination without affecting downstream RNA analyses. Our laboratory tested to see which extraction method provided the most RNA yield with the least amount of DNA contamination; while also determining the effects of DNase treatments from various companies on cDNA after qRT-PCR. 


\section{Methods}

\section{Sample Collection}

Fresh semen samples were collected from a 25 year old, healthy, non-vasectomized male volunteer of European descent. Samples were deposited in a sterile $50 \mathrm{~mL}$ centrifugation tube, provided from the laboratory to the donor. RNA was isolated immediately from the samples and excess sample was discarded. Fresh blood samples were obtained from a 24 year old, healthy, female volunteer of European descent. Samples were pipetted into $1.5 \mathrm{~mL}$ eppendorf tubes. RNA was isolated immediately from the samples and excess sample was discarded. A fresh porcine head was obtained from Emerick Meat \& Packing (Hyndman, PA). All teeth were removed with a hammer and chisel and placed in sterile, $50 \mathrm{~mL}$ centrifugation tubes. The teeth were placed at $-80^{\circ} \mathrm{C}$ until further RNA isolation.

\section{RNA Isolation}

RNA was isolated from blood, semen, and porcine tooth pulp to see the effects of DNase treatments on cDNA. RNA yield and levels of DNA contamination were also compared between various techniques used to extract RNA from porcine tooth pulp.

\section{Blood}

Our laboratory routinely uses MRC Tri-Reagent ${ }^{\circledR}$ BD to isolate DNA-free RNA from blood samples. To prepare for the DNase comparison, $750 \mu \mathrm{L}$ Tri-Reagent ${ }^{\circledR} \mathrm{BD}, 213 \mu \mathrm{L}$ nuclease-free water, $2 \mu \mathrm{L}$ polyacryl carrier, $25 \mu \mathrm{L} 50 \mathrm{mM}$ acetic acid, and $10 \mu \mathrm{L}$ fresh whole blood were placed in $1.5 \mathrm{~mL}$ eppendorf tubes. The samples were vortexed briefly and placed at room temperature for 5 mins. One hundred microliters of 1-bromo-3-chloropropane (BCP) was added and the samples were vortexed for 15 secs. The samples were stored at room temperature for 10mins and then centrifuged in a Beckman Coulter Allegra ${ }^{\mathrm{TM}}$ 25R Centrifuge for 15mins, at $16,000 \mathrm{~g}, 4^{\circ} \mathrm{C}$. The upper, aqueous layer was carefully transferred to a new $1.5 \mathrm{~mL}$ eppendorf tube. Five hundred microliters of isopropanol alcohol was added and the tubes were mixed by inversion. The samples were then stored at room temperature for $8 \mathrm{mins}$ followed by centrifugation for $8 \mathrm{mins}$. The supernatant was removed and $1 \mathrm{~mL} 75 \%$ Ethanol was added. The samples were vortexed followed by centrifugation for 5 mins. The supernatant was removed and 
the samples air-dried under the fume hood for 5mins. Thirty-five microliters of nuclease-free water was added and the samples were mixed by pipetting. The samples were re-suspended by incubation in a $56^{\circ} \mathrm{C}$ water bath for $10 \mathrm{mins}$. The samples were pulse centrifuged and placed on ice until DNase treatment.

\section{Semen}

Because semen contains tightly compacted sperm heads, isolation of RNA must be carried out in the presence of DTT and proteinase K. Proteinase K and DTT help lyse the sperm cells, disrupt the disulfide bonds and hydrolyze the stabilizing membrane proteins found in the sperm cells. Because of this, Tri-Reagent ${ }^{\circledR}$ and many kits are not suitable for the RNA isolation. Therefore, an organic extraction utilizing acidic phenol-chloroform was performed to isolate the RNA.

Ten microliters of fresh liquid semen was placed in $1.5 \mathrm{~mL}$ eppendorf tubes containing $400 \mu \mathrm{L}$ digest buffer (0.01M Tris- $\mathrm{HCl} \mathrm{pH} 7.5,0.01 \mathrm{M}$ EDTA, $0.05 \mathrm{M} \mathrm{NaCl}$, and $2 \% \mathrm{SDS})$. Twelve microliters of $10 \mathrm{mg} / \mathrm{mL}$ Proteinase K and $16 \mu \mathrm{L} \mathrm{1M} \mathrm{DTT} \mathrm{were} \mathrm{added.} \mathrm{The} \mathrm{tubes} \mathrm{were}$ placed in a $56^{\circ} \mathrm{C}$ water bath for $2 \mathrm{hrs}$. After $2 \mathrm{hrs}$ the tubes were pulse centrifuged and $500 \mu \mathrm{L}$ of Ambion 5:1 Phenyl-Chloroform (PC) $\mathrm{pH} 4.5$ was added. The tubes were then vortexed for $15 \mathrm{secs}$ and centrifuged for $10 \mathrm{mins}$ at $16,000 \mathrm{~g}, 4^{\circ} \mathrm{C}$. After centrifugation the upper, aqueous layer was removed and added to a new tube containing $500 \mu \mathrm{L} \mathrm{PC}$. The samples were again vortexed and centrifuged. The aqueous layer containing the nucleic acids was carefully removed and placed in a new $1.5 \mathrm{~mL}$ tube. Sixteen microliters of $5 \mathrm{M} \mathrm{NaCl}$ was added along with $1 \mathrm{~mL}$ of $95 \%$ Ethanol. The samples were then placed at $-80^{\circ} \mathrm{C}$ for $1 \mathrm{hr}$. After $1 \mathrm{hr}$ the samples were centrifuged at $16,000 \mathrm{~g}, 4^{\circ} \mathrm{C}$ for $20 \mathrm{mins}$. The supernatant was then discarded and $500 \mu \mathrm{L}$ of $70 \%$ Ethanol was added. The tubes were briefly vortex and centrifuged for $10 \mathrm{mins}$. A second $70 \%$ ethanol wash was performed. The supernatant was removed and the samples were allowed to air dry for 10mins under the fume hood. Thirty-five microliters of nuclease-free water was then added to the samples and they were placed at $56^{\circ} \mathrm{C}$ for $10 \mathrm{mins}$ for re-suspension. After resuspension the samples were pulse centrifuged and placed on ice until DNase Treatment. 


\section{Tooth Pulp}

Extracting DNA-free RNA from tooth pulp has been shown to be difficult in our laboratory. Therefore, multiple RNA isolation techniques were performed on tooth pulp to compare the amount of RNA and contaminating DNA extracted. First a comparison was performed between four of the different Tri-Reagents on the market. Tri-Reagent ${ }^{\circledR}$, TriReagent ${ }^{\circledR}$ RT, Tri-Reagent ${ }^{\circledR}$ BD, and Tri-Reagent ${ }^{\circledR}$ BD-RT were all tested on tooth pulp following slight adjustments to the manufacturers protocol.

Two porcine teeth were obtained from the $-80^{\circ} \mathrm{C}$ freezer and placed in a mortar. A pestle was used to crack open the teeth. The pulp was placed in a glass tissue grinder containing $1 \mathrm{~mL}$ of nuclease-free water. The pulp was homogenized until all large pieces of the tissue were broken down. Fifty microliters of homogenized tooth pulp was pipetted into $1.5 \mathrm{~mL}$ eppendorf tubes where each Tri-Reagent ${ }^{\circledR}$ protocol was followed on three tubes apiece. All samples were re-suspended in $20 \mathrm{uL}$ of nuclease-free water. The samples were then reverse transcribed and the

levels of DNA and RNA were determined using qPCR. The entire procedure was then replicated on new teeth.

After testing the different Tri-Reagent ${ }^{\circledR}$ protocols, the protocol with the most RNA yield and least DNA contamination was tested against an organic extraction protocol and two kits claiming DNA-free RNA isolations. This was done to help determine which of the isolation techniques would be the most suitable for our laboratory. Two porcine teeth were obtained from the $-80^{\circ} \mathrm{C}$ freezer and cracked open using a mortar and pestle. The tooth pulp was removed and placed in a glass tissue homogenizer containing $1.5 \mathrm{~mL}$ of nuclease-free water. The pulp was ground until no large pieces remained. Fifteen $1.5 \mathrm{~mL}$ eppendorf tubes were obtained, three tubes for each of the five treatments. The 5 treatments were: Tri-Reagent ${ }^{\circledR}$, organic extraction, Qiagen miRNeasy mini Kit with DNase treatment, Qiagen miRNeasy mini Kit without DNase treatment, and Promega SV Total RNA Isolation Kit. The Tri-Reagent ${ }^{\circledR}$ isolation and the organic extraction were followed as previously described whereas the manufactures protocol was followed for each kit. The RNA was re-suspended in 100uL nuclease-free water for all treatments. The samples were then reverse transcribed and the relative quantity of RNA and DNA contamination was determined using $\mathrm{qPCR}$. The entire procedure was then replicated on new teeth. 
To test the effects of DNase on RNA extracted from tooth pulp, RNA was isolated using Tri-Reagent ${ }^{\circledR}$ RT. A tooth was obtained from the $-80^{\circ} \mathrm{C}$ freezer and cracked open using a mortar and pestle. The tooth parts were removed and the tooth pulp was placed in a glass tissue grinder containing $3.5 \mathrm{~mL}$ of Tri-Reagent ${ }^{\circledR} \mathrm{RT}$. The tissue was ground until no large pieces remained. Two hundred microliters of pulp mixture was placed into $151.5 \mathrm{~mL}$ tubes. Eight hundred microliters of Tri-Reagent ${ }^{\circledR}$ RT was added to each tube and vortexed briefly. Fifty microliters of Bromoanisole was added and the samples were vortexed for $15 \mathrm{sec}$. The samples were then centrifuged at $16,000 \mathrm{~g}$ for $15 \mathrm{mins}, 4^{\circ} \mathrm{C}$. Five hundred microliters of the upper, aqueous layer was removed and placed in a new tube containing $500 \mu \mathrm{L}$ of isopropanol. The samples were inverted to mix and stored at room temperature for $8 \mathrm{mins}$. The samples were then centrifuged for 5mins. The supernatant was removed and placed in a new tube containing $1 \mathrm{~mL}$ of $75 \%$ Ethanol. The samples were vortexed and centrifuged for 5 mins. The supernatant was removed and $35 \mu \mathrm{L}$ of nuclease-free water was added. The samples were incubated for 10mins at $56^{\circ} \mathrm{C}$, pulse centrifuged, and placed on ice until DNase treatment.

\section{DNase Treatments}

RNA isolated from semen, blood, and tooth pulp was treated with DNase to see the effects of the treatments on both DNA and cDNA using qRT-PCR. The use of a particular DNase treatment for forensic purposes was only deemed suitable if it rid the sample of contaminating DNA but did not affect the resulting cDNA. DNase from Ambion, Qiagen and Promega were compared. Ambion's TURBO DNA-free ${ }^{\text {TM }}$ (Part \#: AM1907) uses an inactivation reagent to inactivate the DNase prior to RT-PCR. Qiagen's RNase-Free DNase (Catalog \#: 79254) and Promega's RQ1 RNase-Free DNase (Catalog \#: M6101) both utilize heat inactivation to denature the DNase enzyme prior to RT-PCR. Five DNase treatments were performed on the three sample types. For each treatment, every sample was divided in half so that half received the DNase treatment and the other half did not. After DNase treatment all samples were reverse transcribed and quantified using qPCR to compare DNase treatments versus no DNase treatments. 


\section{Ambion TURBO ${ }^{\mathrm{TM}}$ DNA-Free DNase}

Each tube containing a $35 \mu \mathrm{L}$ sample was divided into two $0.5 \mathrm{~mL}$ tubes containing $15 \mu \mathrm{L}$ each. To one of the $15 \mu \mathrm{L}$ samples, $1.5 \mu \mathrm{L} 10 \mathrm{x}$ DNase buffer was added along with $1 \mu \mathrm{L}$ DNase. To the other $15 \mu \mathrm{L}$ sample, $1.5 \mu \mathrm{L} 10 \mathrm{x}$ DNase buffer was added along with $1 \mu \mathrm{L}$ nuclease-free water. This was repeated for all replicates. The samples were vortexed, pulse centrifuged, and incubated at $37^{\circ} \mathrm{C}$ for $30 \mathrm{mins}$. Two microliters of inactivation reagent were added and the samples were again vortexed and pulse centrifuged. The samples sat at room temperature for 5mins and were mixed occasionally by pulse vortexing. The samples were then centrifuged for 2 mins at $16,000 \mathrm{~g}$. Fifteen microliters of the supernatant was removed and placed in a new tube leaving behind the inactivation reagent pellet.

\section{Ambion TURBO ${ }^{\mathrm{TM}}$ DNA-Free DNase: Heat Inactivation}

Each tube containing a $35 \mu \mathrm{L}$ sample was divided into two $0.5 \mathrm{~mL}$ tubes containing $15 \mu \mathrm{L}$ each. To one of the $15 \mu \mathrm{L}$ samples, $1.5 \mu \mathrm{L} 10 \mathrm{x}$ DNase buffer was added along with $1 \mu \mathrm{L}$ DNase. To the other $15 \mu \mathrm{L}$ sample, $1.5 \mu \mathrm{L} 10 \mathrm{x}$ DNase buffer was added along with $1 \mu \mathrm{L}$ nuclease-free water. This was repeated for all replicates. The samples were vortexed, pulse centrifuged, and incubated at $37^{\circ} \mathrm{C}$ for $30 \mathrm{mins}$. Two microliters of 50mM EDTA was added to each tube and the samples were again vortexed and pulse centrifuged. The tubes were then incubated at $65^{\circ} \mathrm{C}$ for $10 \mathrm{mins}$ and pulse centrifuged.

\section{Ambion TURBO ${ }^{\mathrm{TM}}$ DNA-Free DNase: Non-Stick Tubes}

For the third treatment, tubes were processed using the Ambion DNase protocol with non-stick tubes. Non-stick tubes prevent the DNase enzyme from sticking to the eppendorf tubes, thus preventing it from getting carried over into the RT-PCR reaction. These tubes were recommended to our laboratory from Ambion. The original Ambion protocol was repeated as before but instead $3 \mu \mathrm{L}$ of 10x DNase Buffer, $1 \mu \mathrm{L}$ DNase, and $30 \mu \mathrm{L}$ nuclease-free water was added to one of the $15 \mu \mathrm{L}$ tubes and the other received $31 \mu \mathrm{L}$ nuclease-free water and $3 \mu \mathrm{L}$ of $10 \mathrm{x}$ DNase Buffer. Three microliters of inactivation reagent was added and $19 \mu \mathrm{L}$ of the supernatant was removed to a new tube. 


\section{Promega RQ1 RNase-Free DNase}

Each tube containing a $35 \mu \mathrm{L}$ sample was divided into two $0.5 \mathrm{~mL}$ tubes containing $15 \mu \mathrm{L}$ each. To one of the $15 \mu \mathrm{L}$ samples, $2 \mu \mathrm{L} 10 \mathrm{x}$ DNase Buffer, $1 \mu \mathrm{L}$ nuclease-free water, and $2 \mu \mathrm{L}$ DNase were added. To the other $15 \mu \mathrm{L}, 2 \mu \mathrm{L}$ 10x DNase Buffer and $3 \mu \mathrm{L}$ nuclease-free water were added. The tubes were vortexed and pulse centrifuged. The samples were then incubated at $37^{\circ} \mathrm{C}$ for $30 \mathrm{mins}$. Two microliters stop solution was added, the samples were vortexed, and then pulse centrifuged. The samples were then incubated at $65^{\circ} \mathrm{C}$ for $10 \mathrm{mins}$ to inactivate the DNase enzyme.

\section{Qiagen RNase-Free DNase}

Each tube containing a $35 \mu \mathrm{L}$ sample was divided into two $0.5 \mathrm{~mL}$ tubes containing $15 \mu \mathrm{L}$ each. To one of the $15 \mu \mathrm{L}$ samples, $2 \mu \mathrm{L} 10 \mathrm{x}$ DNase buffer, $0.5 \mu \mathrm{L}$ RNase inhibitor, $2 \mu \mathrm{L}$ nuclease-free water, and $0.5 \mu \mathrm{L}$ DNase was added. To the other $15 \mu \mathrm{L}$ sample, $2 \mu \mathrm{L} 10 \mathrm{x}$ DNase buffer, $0.5 \mu \mathrm{L}$ RNase inhibitor, and $2.5 \mu \mathrm{L}$ nuclease-free water were added. The samples were vortexed, pulse centrifuged, and incubated at $37^{\circ} \mathrm{C}$ for $30 \mathrm{mins}$. Two microliters of $50 \mathrm{mM}$ EDTA was added, the tubes were pulse centrifuged, and incubated at $65^{\circ} \mathrm{C}$ for $5 \mathrm{mins}$.

\section{Reverse Transcription}

Total isolated RNA was converted to cDNA using RT-PCR. Applied Biosystem's TaqMan® Gold RT-PCR Kit was used for all reverse transcription reactions. A reverse transcription master mix was made containing final concentrations: 1X TaqMan® RT Buffer, $5.5 \mathrm{mM}$ magnesium chloride, $500 \mu \mathrm{M}$ each dATP, dCTP, dGTP, and dTTP, and $2.5 \mu \mathrm{M}$ random hexamers. Each reverse transcription reaction consisted of $28.5 \mu \mathrm{L}$ master mix, $1.0 \mu \mathrm{L}$ RNase inhibitor $(0.4 \mathrm{U}), 1.25 \mu \mathrm{L}$ multiscribe reverse transcriptase $(1.875 \mathrm{U})$, and $19.3 \mu \mathrm{L}$ RNA suspension (water was added to bring total volume up to 19.3 if needed) for a total of $50 \mu \mathrm{L}$. Reverse transcription samples were pulse vortexed and centrifuged. The samples were then placed in a Techne Touchgene Gradient Thermocycler and converted to single stranded cDNA using one cycle under the following conditions: $25^{\circ} \mathrm{C}$ for $10 \mathrm{mins}$ to anneal random hexamer primers, $48^{\circ} \mathrm{C}$ for $30 \mathrm{mins}$ to extend the primers, $90^{\circ} \mathrm{C}$ for 5 mins to eliminate contaminating RNA, and $4^{\circ} \mathrm{C}$ final hold. Samples were then amplified using qPCR. 


\section{Real-Time Polymerase Chain Reaction}

Single stranded cDNA was then converted to double stranded cDNA, amplified, and quantified using qPCR. Singleplex reactions were performed on all samples. All semen samples were amplified using GapNT-201 and PRM1-72 previously described. Gap was run to detect levels of DNA contamination and PRM1-72 to detect RNA yield present in the samples. The concentrations of forward and reverse primers for GapNT-201 were 900nM and the probe was set at $250 \mathrm{~nm}$. The concentrations of forward and reverse primers for PRM1-72 were 150nm and the probe was set at $250 \mathrm{~nm}$.

All blood samples were amplified using GapNT-201 and Ba4 primer pairs. Ba4 primer pairs were designed to amplify a segment $89 \mathrm{bp}$ in length present on $\beta$-actin mRNA. Gap was run to detect levels of DNA contamination and Ba4 to detect RNA yield present in the samples. The concentrations of forward and reverse primers for $\mathrm{Ba} 4$ were $150 \mathrm{~nm}$ and the probe was set at $250 \mathrm{~nm}$.

All porcine tooth pulp samples were amplified using PGapNT-71 and PBA-71. PGapNT-71 amplifies a 71bp amplicon if DNA contamination is present. PBA-71 primer pairs were designed to amplify a segment 71bp in length present on porcine $\beta$-actin mRNA and is used to detect RNA yield present in the samples. The concentrations of forward and reverse primers for both PGapNT-71 and PBA-71 were 150nm and the probes were set at 250nm.

Final concentrations for the $\mathrm{qPCR}$ mix for each reaction were: primer $\&$ probe concentrations specified for each primer pair, $12.5 \mu \mathrm{L}$ of Applied Biosystems TaqMan® Universal PCR Master Mix, and nuclease-free water to bring the final volume of the reaction to $20 \mu \mathrm{L}$. Five microliters of sample was added to the mix and duplicates were run for each sample. Samples were run in an Applied Biosystems 7300 Real-Time PCR System under the following parameters: 1 cycle at $50^{\circ} \mathrm{C}$ for 2 minutes, 1 cycle at $95^{\circ} \mathrm{C}$ for 10 minutes, and 40 cycles at $95^{\circ} \mathrm{C}$ for 15 seconds followed by $60^{\circ} \mathrm{C}$ for 1 minute. For every real-time run, both positive and negative (nuclease-free water plus master mix) controls were run.

\section{Data Analysis}

After amplification using qPCR, Ct values were obtained for both DNA and RNA primer pairs for all sample types. The $\mathrm{Ct}$ values were obtained by selecting a region within the log linear phase of the exponential growth above any background noise. Relative quantification 
analysis of the data was performed using Applied Biosystems Sequence Detection Software Version 1.3. The data were exported into Microsoft Excel for further analysis. Once in Excel, the average $\mathrm{Ct}$ value for each sample was determined along with the standard deviation and standard error.

\section{DNase Analysis}

The average DNA contamination levels before the DNase treatments were determined by calculating the 40 minus $\mathrm{Ct}(40-\mathrm{Ct})$ value obtained from either GapNT-201 or PGapNT-71. Ct values are not logical in the sense that the smaller the number the more nucleic acid is present. Therefore, by using 40-Ct it allows for a more logical representation of the amount of starting material present if 40 cycles were run during the PCR reaction. Our laboratory has determined that a $\mathrm{Ct}$ value over 35 is indicative of background noise; therefore, if the 40-Ct value was above five, then the level of DNA contamination is enough to cause errors in our analysis for projects that use primers not specific for RNA. The effect of DNase on cDNA was determined by calculating the average DNase $\mathrm{Ct}$ minus average No DNase $\mathrm{Ct}$. Because all volumes and conditions were identical for samples treated with DNase and without, the $\mathrm{Ct}$ values should be equal if the DNase does not affect cDNA yield after qRT-PCR. Because the machine has a possible error rate of $0.5 \mathrm{Ct}$ per well, any difference greater than one was indicative of degradation of cDNA by DNase. The average DNA contamination and cDNA degradation was plotted in Excel for all three biological sample types and all five DNase treatments.

\section{Tri-Reagent ${ }^{\circledR}$ Comparison}

To compare the various Tri-Reagent ${ }^{\circledR}$ products on RNA yield and DNA contamination obtained from porcine tooth pulp, the average $40-\mathrm{Ct}$ values were calculated. The Tri-Reagent ${ }^{\circledR}$ would be considered successful in producing DNA-free RNA if the 40-Ct values were below five; therefore, the lower the 40-Ct value calculated using PGapNT-71 the less DNA contamination present. The opposite was true for RNA yield; the higher the 40-Ct value obtained for the PBA-71 primer pair, the more RNA was isolated. The average DNA contamination and RNA yield were plotted in Excel for all four Tri-Reagent ${ }^{\circledR}$ treatments. 


\section{Kit, Tri-Reagent, and Organic Isolation Comparison}

To compare the various isolation protocols on RNA yield and DNA contamination obtained from porcine tooth pulp, the average 40-Ct values were calculated. The average DNA contamination and RNA yield were plotted in Excel for all five isolation protocols.

\section{Statistical Analysis}

The two-tailed Matched-Pair Student's t-Test was performed on samples treated with and without DNase to determine if there was a difference between RNA derived signal obtained when DNase was employed. For all five DNase treatments, DNase and no DNase Ct values were compared and the level of significance was determined using $\alpha=0.05$. Ideally, the average $\mathrm{Ct}$ difference of zero is preferred which indicates no cDNA loss; therefore the levels of significance were determined using this value to remain conservative. Because the real-time machine has a potential $0.5 \mathrm{Ct}$ error per well, the DNase treatment was still accepted regardless of the level of significance if the DNase minus No DNase $\mathrm{Ct}$ value was found to be below one. Although accepted here, caution should be taken when the results were deemed significant.

The two-tailed Matched-Pair Student's t-Test was performed on porcine tooth pulp samples extracted using the various isolation protocols to determine if there was a difference in the amount of nucleic acid extracted between techniques. All isolation techniques (including the Tri-Reagent ${ }^{\circledR}$ comparison and Tri-Reagent ${ }$, PCI, and kit comparison) were compared to each other individually to determine which isolated the most RNA and least DNA contamination. The $40-\mathrm{Ct}$ values were compared and the level of significance was determined using $\alpha=0.05$.

Levels of significance were determined as follows: $\mathrm{p}<0.001$ extremely significant $(* * *)$, $0.001<\mathrm{p}<0.01$ very significant $(* *), 0.01<\mathrm{p}<0.05$ significant $(*)$, and $\mathrm{p}>0.05$ not significant. 


\section{Results}

Results from the Tri-Reagent ${ }^{\circledR}$ isolation comparisons on porcine tooth pulp are presented in Figure 2-1. All Tri-Reagent ${ }^{\circledR}$ protocols were successful at obtaining high quantities of RNA but none were able to successfully free the samples of contaminating DNA. Regular TriReagent ${ }^{\circledR}$ was found to be significant for isolating higher RNA levels and extremely significant for isolating lower DNA contamination levels when compared to all other protocols; however, when RNA specific primers cannot be designed none of the reagents are suitable without taking additional steps to eliminate the DNA. Tri-Reagent ${ }^{\circledR}$ was then compared to an organic extraction, the Qiagen miRNeasy mini kit that includes an optional DNase treatment, and the Promega SV Total RNA Isolation Kit. The results of the comparison are presented in Figure 2-

2. It was determined that in order to rid samples of DNA contamination using these isolation procedures, DNase must be utilized. The Qiagen miRNeasy mini kit was successful at ridding samples of DNA contamination when the optional DNase treatment was included in the protocol. The Promega SV Total RNA Isolation Kit utilizes a DNase treatment but was not found to be successful at ridding all samples of DNA contamination. The most successful isolation technique that does not utilize DNase was found to be Tri-Reagent ${ }^{\circledR}$. The organic extraction was extremely significant for isolating higher DNA contamination levels, the Qiagen miRNeasy mini kit including DNase treatment was very significant for isolating lower DNA levels, and the Promega SV Total RNA Isolation Kit with DNase treatment was very significant for isolating lower RNA levels when compared to all other isolation techniques. All other comparisons were not significant when comparing the amount of nucleic acid isolated.

To determine if DNase has an effect on cDNA after qRT-PCR, different DNase protocols were followed on blood, semen, and tooth pulp. The organic extraction and Tri-Reagent@-RT protocols for isolating RNA from semen and tooth pulp respectively, produced DNA contamination levels higher than what would be considered background noise (40-Ct values greater than five). Tri-Reagent ${ }^{-B D}$ was successful at producing DNA-free RNA from blood samples (see Figure 2-3). All five DNase protocols were successful at eliminating contaminating DNA from blood, semen, and porcine tooth pulp. Any signal still present fell in the range of background noise (see Figure 2-4).

The effects of DNase treatments on cDNA yield using qRT-PCR are presented in Table 2-1 and Figures 2-5:8. For all biological samples, the Ambion TURBO ${ }^{\mathrm{TM}}$ DNA-free DNase 
treatment resulted in an estimated 45-fold loss of RNA-derived signal when following the Ambion protocol. When the Ambion protocol was followed using non-stick tubes, an estimated 108 fold loss of RNA-derived signal was observed. Heat inactivation of the DNase enzyme, rather than using Ambion's inactivation reagent, was able to rescue the Ambion protocol, eliminating cDNA loss for semen and tooth pulp samples. Promega's RQ1 RNase-Free DNase and Qiagen's RNase-Free DNase, which utilize heat inactivation, did not produce a loss in cDNA signal; the $\mathrm{Ct}$ values remained within acceptable experimental error range with and without DNase treatment on semen and tooth pulp samples. When the biological sample was blood and therefore no DNA contamination was present, all DNase treatments had a minor affect on Ba4 cDNA yield. On average the use of DNase to remove contaminating DNA resulted in significant loss of RNA-derived signal. However when a value of 1 was used to compare the difference between DNase and no DNase treatments (which allows for slight machine error) heat inactivation of the DNase enzyme results in no cDNA loss and inactivation reagents results in extremely significant cDNA loss (See Figure 2-8).

Overall it was determined that DNase treatment on RNA samples was acceptable at producing DNA-free RNA if the DNAse was inactivated using heat instead of an inactivation reagent. It was also determined that samples should only be treated with DNAse if DNA contamination is higher than background (40-Ct values greater than five). 


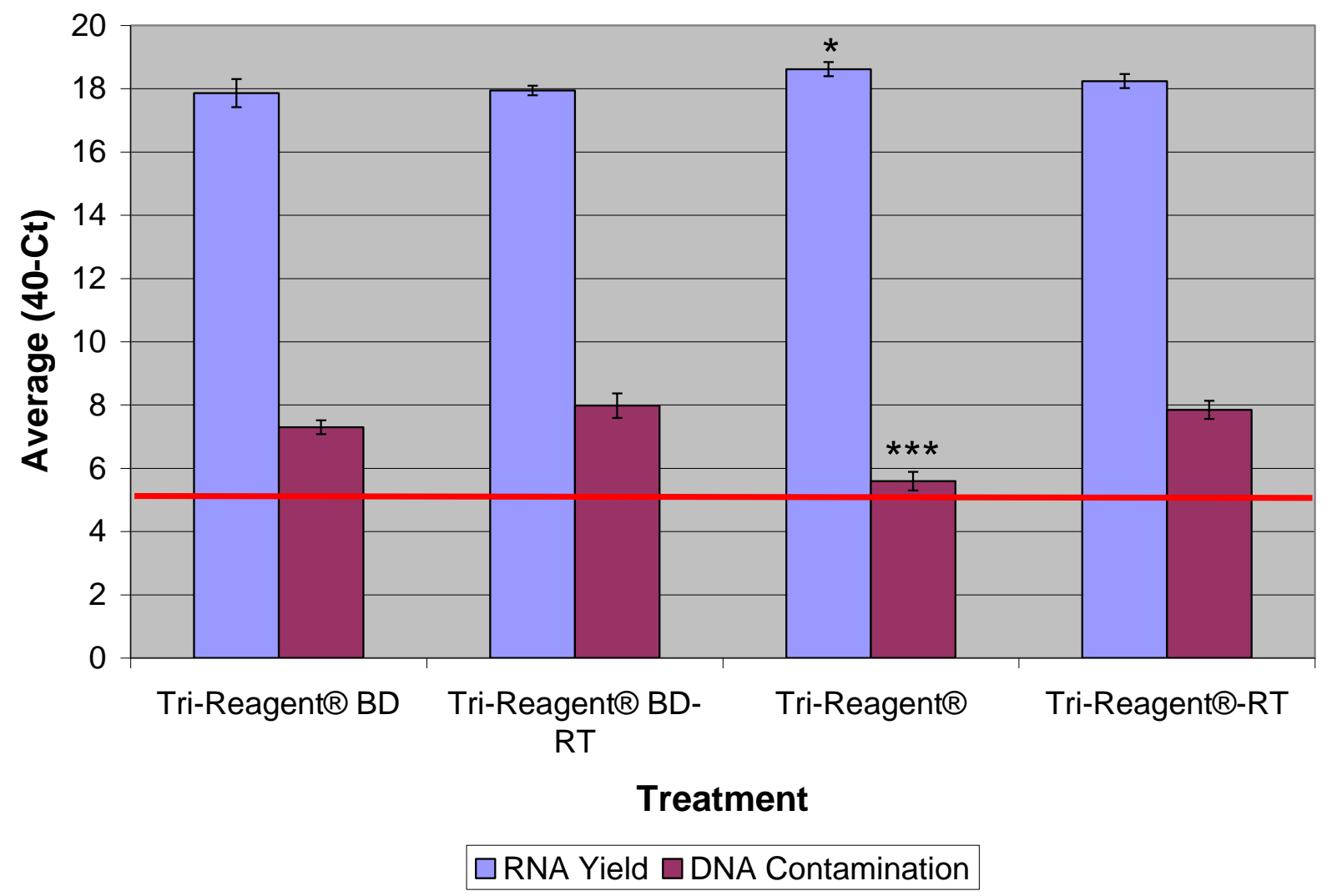

Figure 2-1: Average DNA \& RNA levels isolated from porcine tooth pulp using various Trireagent ${ }^{\circledR}$ protocols. Higher 40 minus $\mathrm{Ct}(40-\mathrm{Ct})$ values indicate more starting material in the sample. The red-line signifies background noise; therefore isolation techniques were only successful at producing DNA-free RNA if the DNA contamination levels fell below this line. Levels of significance were determined as follows: $p<0.001$ extremely significant $(* * *), 0.001<$ $\mathrm{p}<0.01$ very significant $(* *), 0.01<\mathrm{p}<0.05$ significant $(*)$, and $\mathrm{p}>0.05$ not significant. 


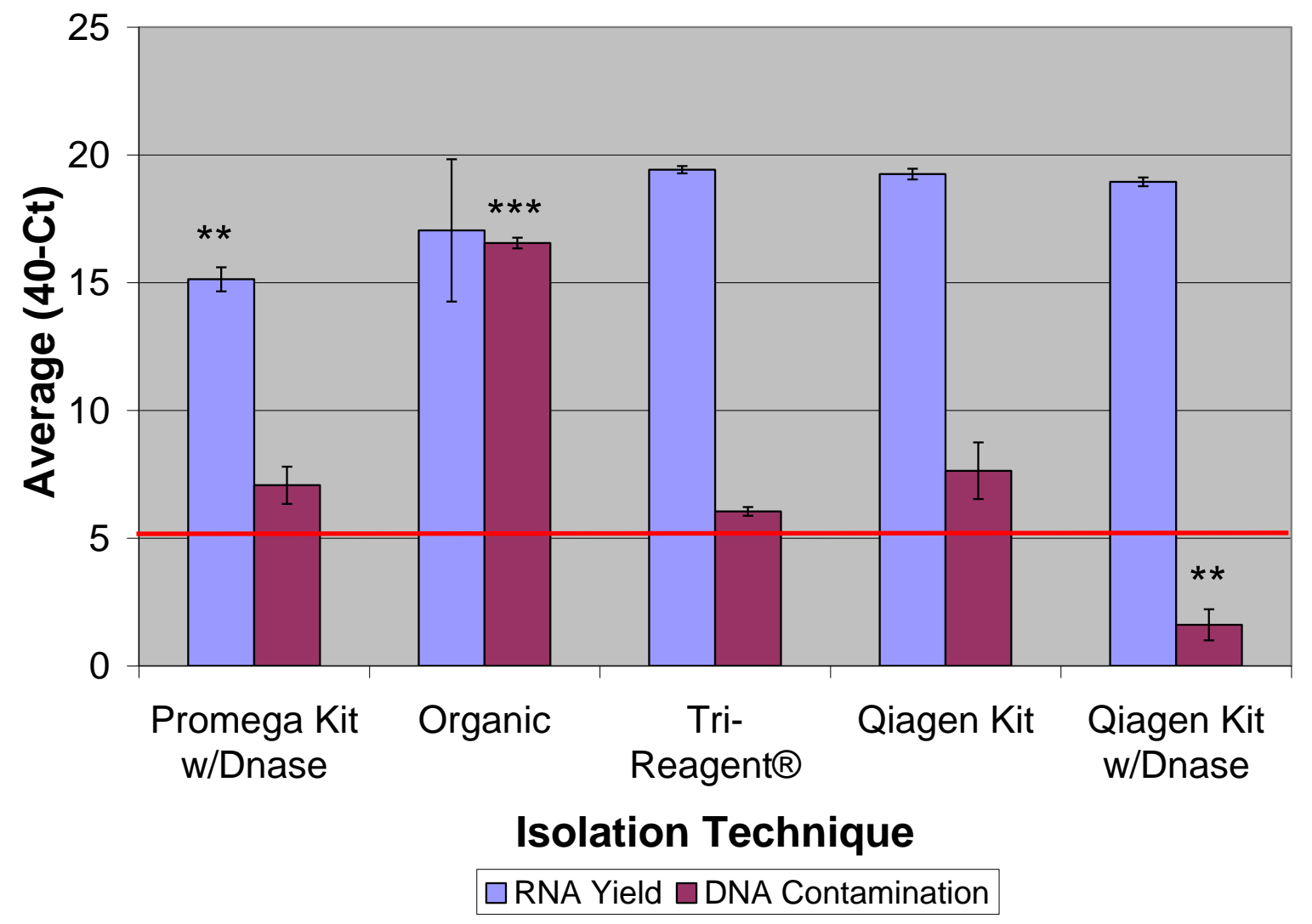

Figure 2-2: Average DNA \& RNA levels isolated from porcine tooth pulp using various isolation techniques. Higher 40 minus $\mathrm{Ct}(40-\mathrm{Ct})$ values indicate more starting material in the sample. The red-line signifies background noise; therefore isolation techniques were only successful at producing DNA-free RNA if the DNA contamination levels fell below this line. Levels of significance were determined as follows: $p<0.001$ extremely significant $(* * *), 0.001<$ $\mathrm{p}<0.01$ very significant $(* *), 0.01<\mathrm{p}<0.05$ significant $(*)$, and $\mathrm{p}>0.05$ not significant. 
Table 2-1: Loss of cDNA following various DNase treatments

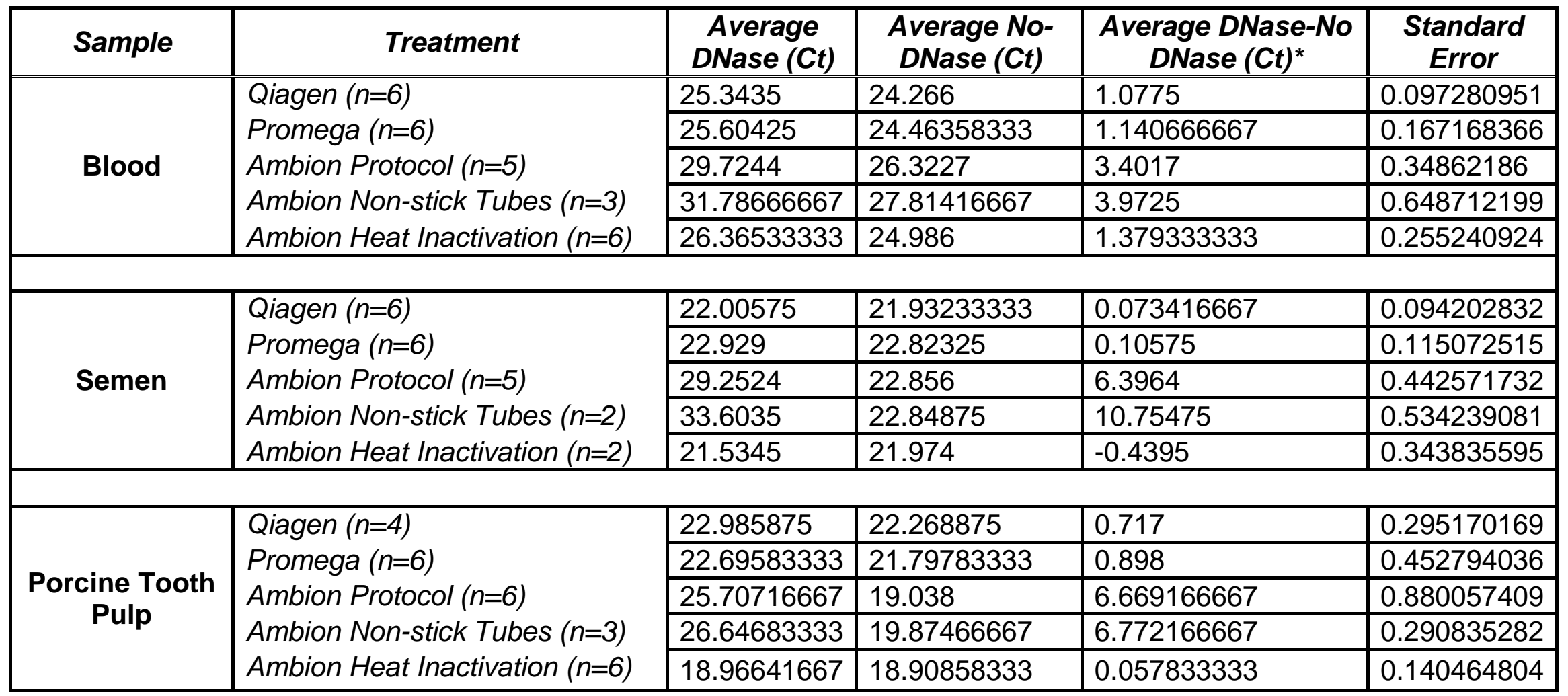

*Average DNase-No DNase Ct values greater than one indicate a loss of RNA derived signal. The higher the value, the greater the negative effect of the DNase treatment. 


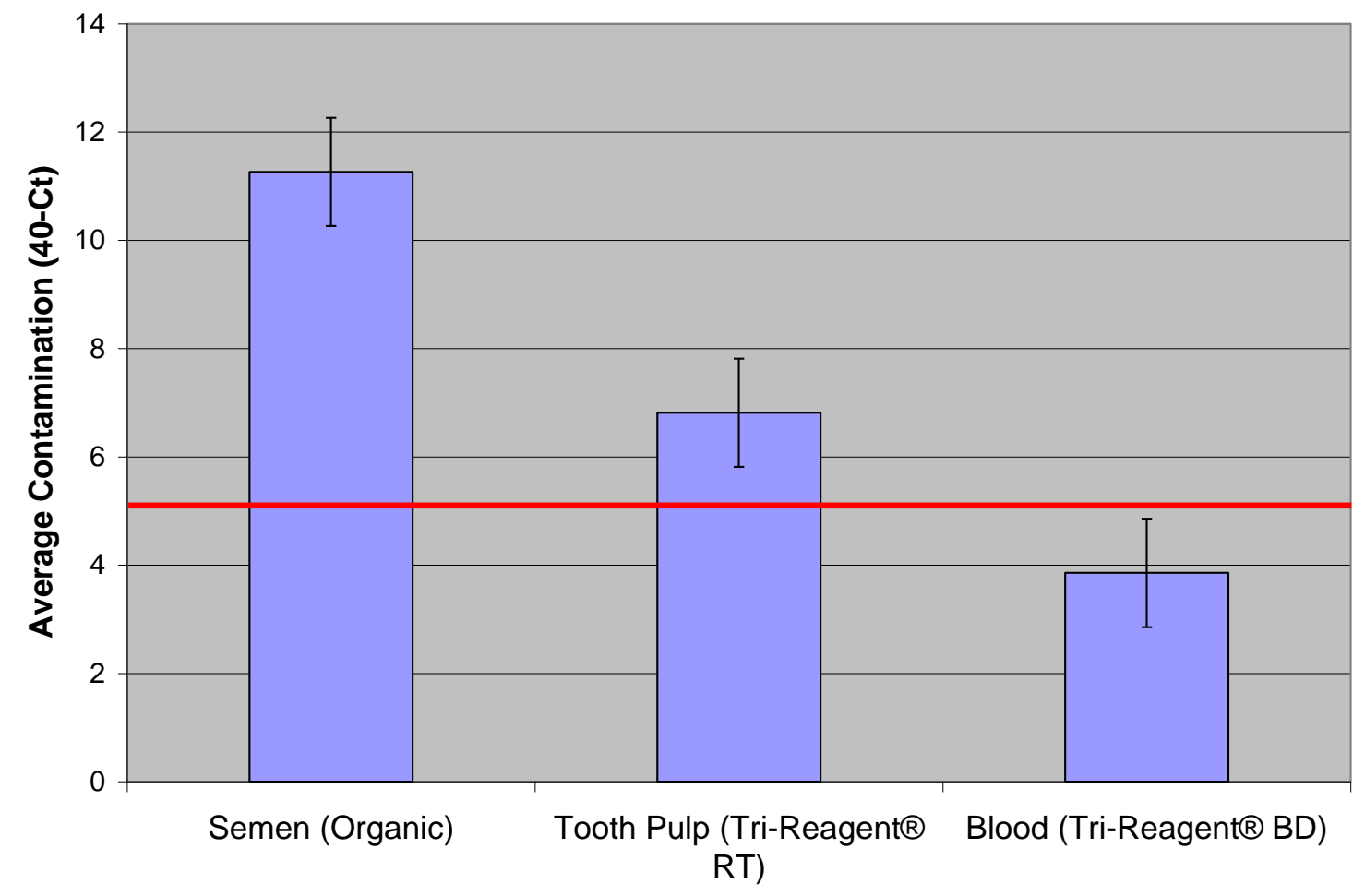

Figure 2-3: DNA contamination present after various isolation protocols prior to DNase Treatments. Both the organic and Tri-Reagent ${ }^{\circledR}$ RT isolations contained DNA contamination levels, for their respective samples types, over the threshold allowed by our laboratory. This threshold is indicated by the red-line. Tri-Reagent ${ }^{\circledR} \mathrm{BD}$ was successful at producing DNA-free RNA isolates from blood samples. 


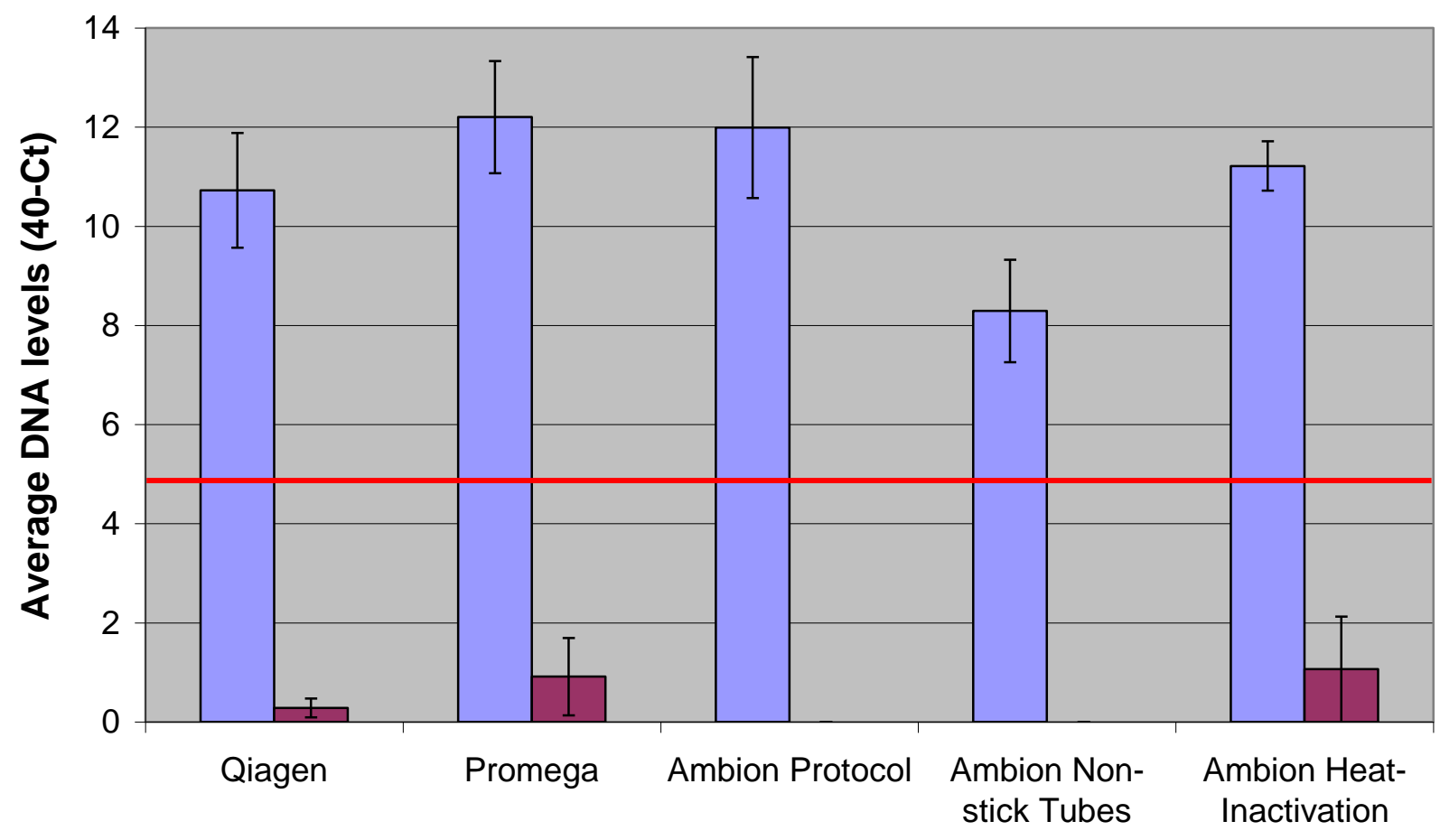

DNase Treatment

\section{$\square$ Before $\square$ After}

Figure 2-4: Average GapNT-201 DNA contamination present in semen stains before and after various DNase treatments. To ensure that the DNase enzyme was working properly, the samples which had the highest amounts of DNA contamination, semen, were tested to see if all DNA signal was eliminated. Treatments were successful at removing contaminating DNA if the 40-Ct values were found to be below background noise, shown by the red-line. 


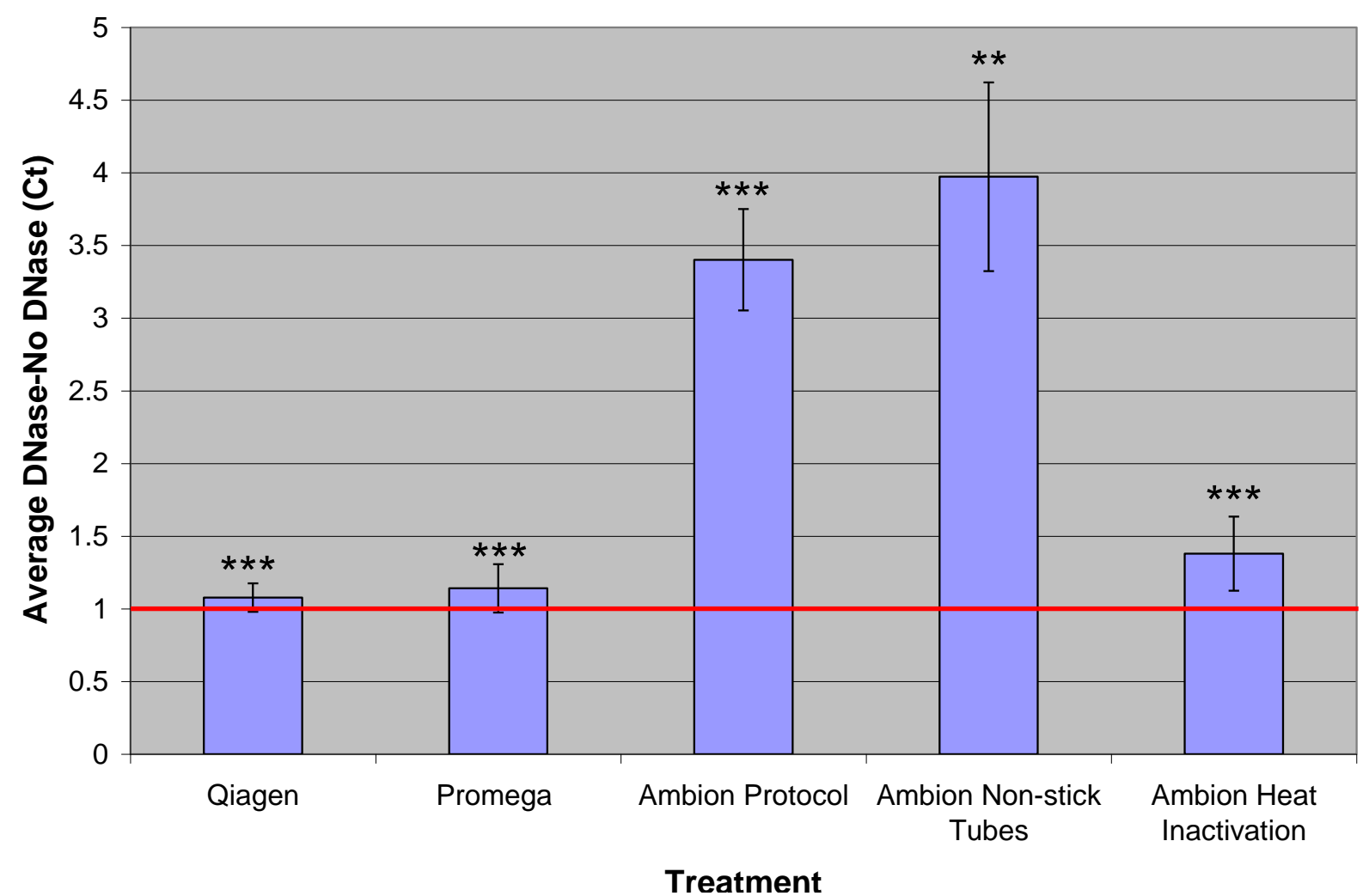

Figure 2-5: Average loss of blood Ba4 cDNA after various DNase treatments. When no DNA contamination was present, all DNase treatments significantly lost cDNA when compared to no DNase treatments. The red-line signifies acceptable experimental error range; anything above this line signifies cDNA loss with DNase treatment. Levels of significance were determined as follows: $\mathrm{p}<0.001$ extremely significant $(* * *), 0.001<\mathrm{p}<0.01$ very significant $(* *), 0.01<\mathrm{p}<0.05$ significant $(*)$, and $\mathrm{p}>0.05$ not significant. 


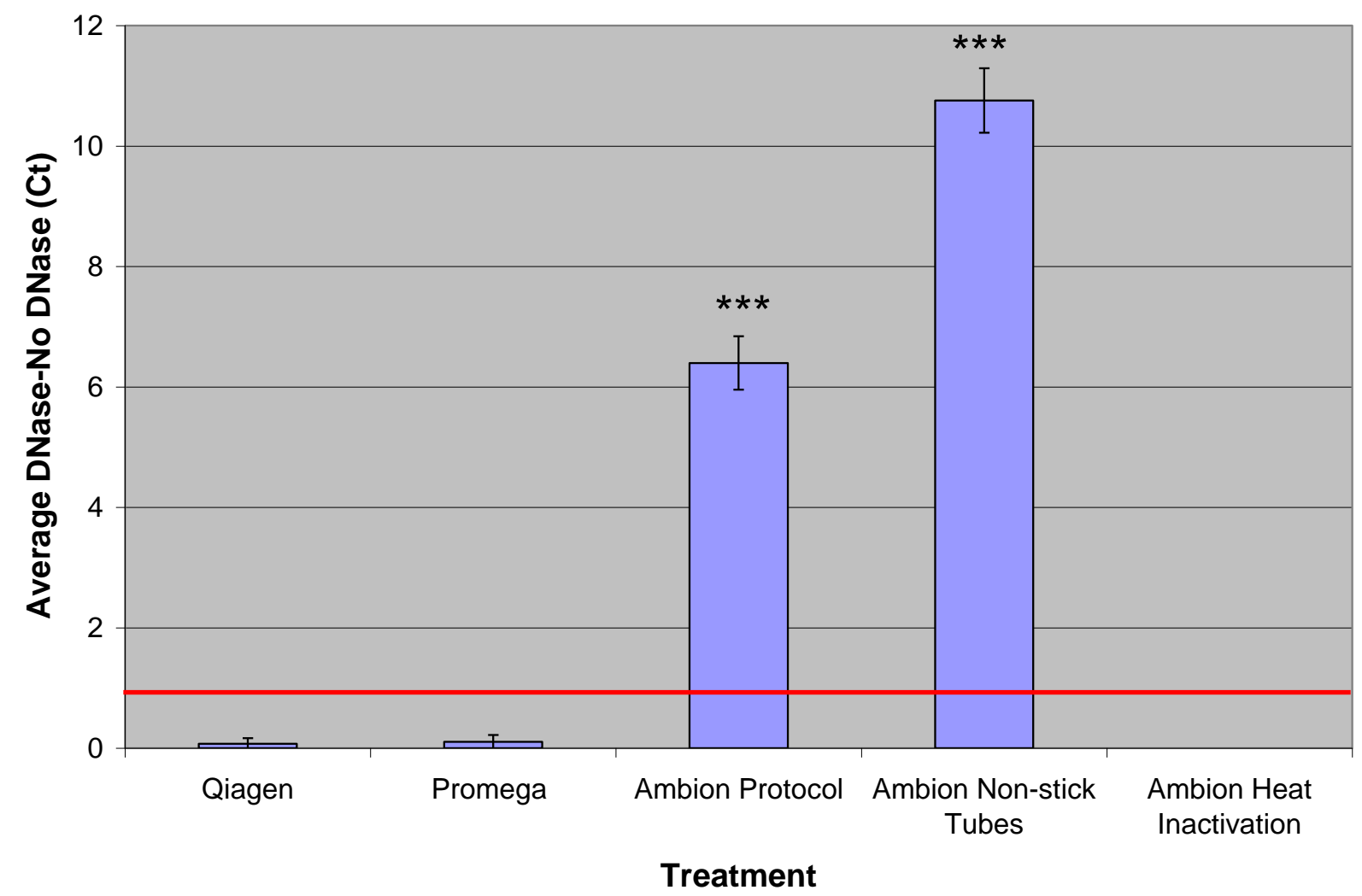

Figure 2-6: Average loss of semen PRM1 cDNA after various DNase treatments. No loss of cDNA was observed when heat inactivation of the DNase enzyme was utilized. When an inactivation reagent was utilized to remove the DNase enzyme the results were extremely significant in regards to cDNA loss. The red-line signifies acceptable experimental error; anything above this line signifies cDNA loss with DNase treatment. Levels of significance were determined as follows: $\mathrm{p}<0.001$ extremely significant $(* * *), 0.001<\mathrm{p}<0.01$ very significant $(* *), 0.01<\mathrm{p}<0.05$ significant $(*)$, and $\mathrm{p}>0.05$ not significant. 


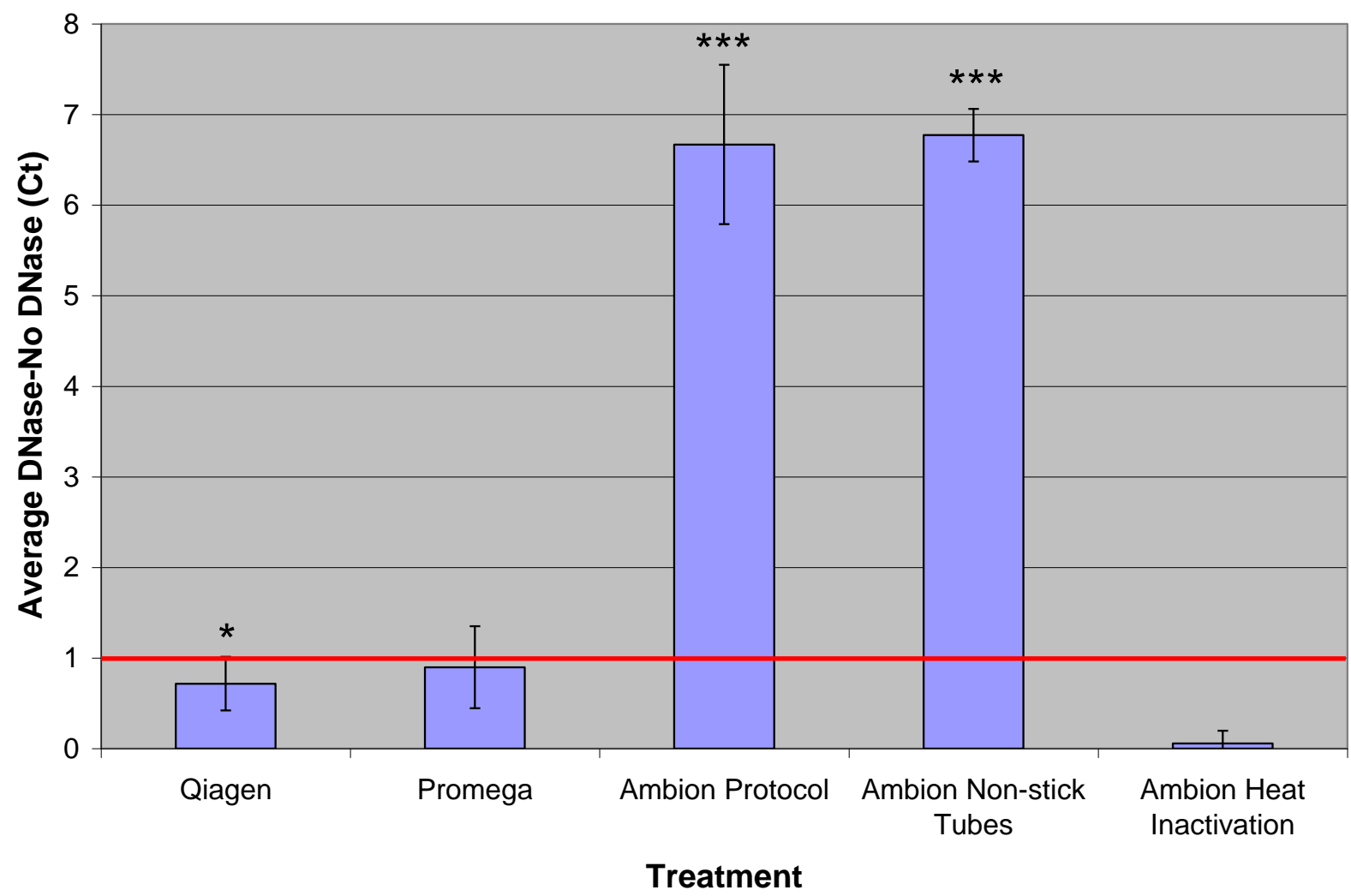

Figure 2-7: Average loss of porcine tooth pulp PBA-71 cDNA after various DNase

Treatments. Loss of cDNA was minimal when heat inactivation of the DNase enzyme was utilized. When an inactivation reagent was employed to remove the DNase enzyme the results were extremely significant in regards to cDNA loss. The red-line signifies acceptable experimental error; anything above this line signifies cDNA loss with DNase treatment. Levels of significance were determined as follows: $\mathrm{p}<0.001$ extremely significant $(* * *), 0.001<\mathrm{p}<$ 0.01 very significant $(* *), 0.01<\mathrm{p}<0.05$ significant $(*)$, and $\mathrm{p}>0.05$ not significant. 


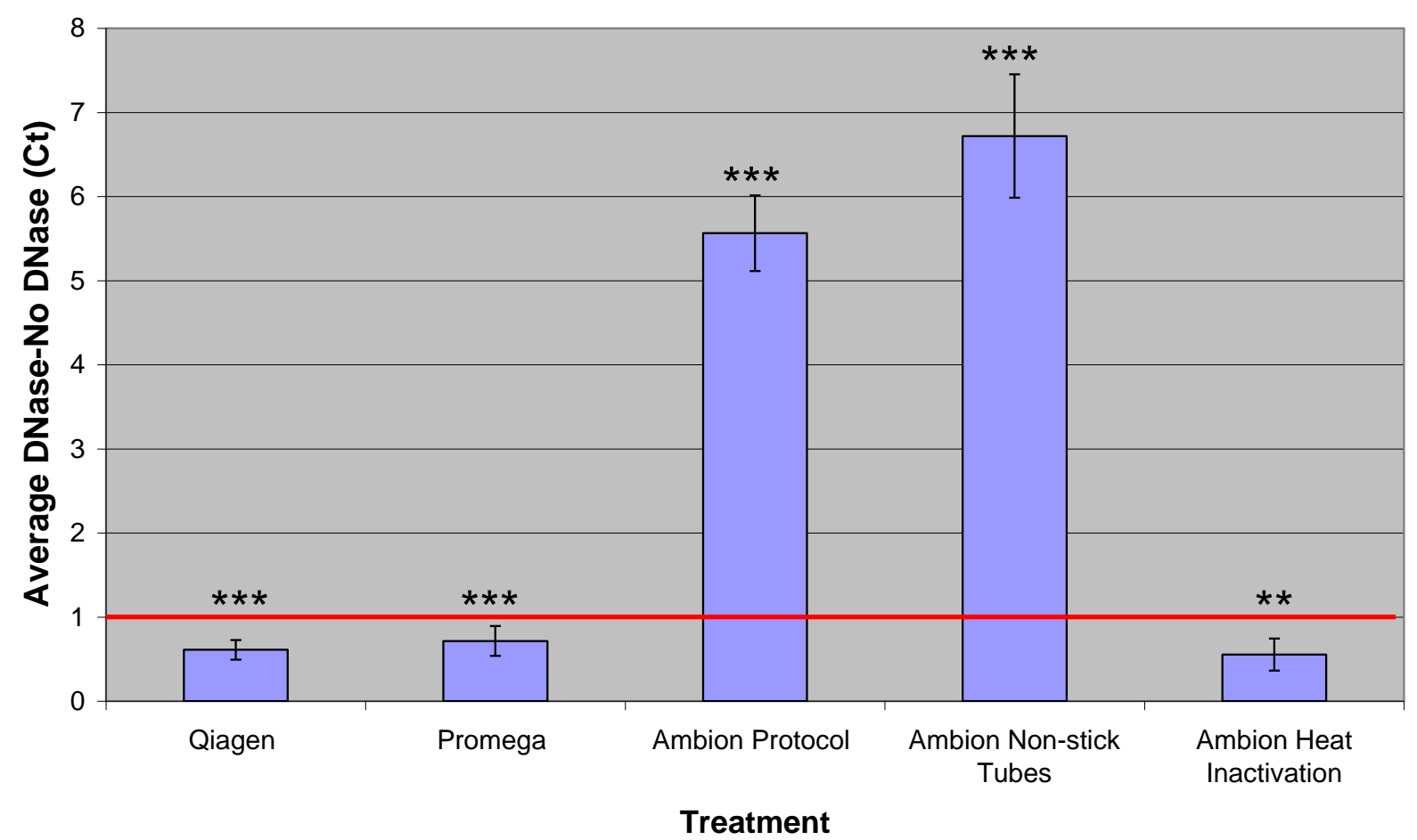

Figure 2-8: Average loss of cDNA following various DNase Treatments. Semen, blood, and porcine data were averaged to determine the overall loss of cDNA using the five different DNase treatments. Levels of significance were determined as follows: $p<0.001$ extremely significant $(* * *), 0.001<\mathrm{p}<0.01$ very significant $(* *), 0.01<\mathrm{p}<0.05$ significant $(*)$, and $\mathrm{p}>0.05$ not significant. 


\section{Discussion}

Obtaining DNA-free RNA is crucial when primers cannot be made RNA specific. When this is the case, contaminating DNA can cause results to be inaccurate. This is especially important when the amount of starting RNA affects the outcome of the results or when trying to identify a type of sample based on the mRNAs expressed. When ample stain is present, DNA and RNA can be isolated separately. For some types of biological stains, such as blood, this is sufficient because techniques exist that produce DNA-free RNA relatively easily. With semen and tooth pulp, producing DNA-free RNA is more difficult. When isolation comparisons were performed on porcine tooth pulp, it was determined that none of the techniques were suitable for producing DNA-free RNA. Any DNA contamination above background could potentially interfere with RNA analysis if primers and probes bind to the DNA template. The use of DNAse was the only technique investigated that was able to rid samples of contaminating DNA.

According to MRC gene, Tri-Reagent ${ }^{\circledR}$ RT contains an upgraded reagent to be used for single-step isolations. When tooth pulp is the biological material, Tri-Reagent ${ }^{\circledR}$ RT was not able to produce DNA-free RNA and regular Tri-Reagent ${ }^{\circledR}$ was found to be the most successful; however DNA was still obtained that registered above background noise (40-Ct greater than five). Qiagen's miRNeasy mini kit was not successful at producing DNA-free RNA unless the optional DNase step was utilized. When the DNase step was used, high levels of RNA were isolated that were devoid of contaminating DNA. The Promega SV Total RNA Isolation Kit, which includes a DNase treatment, was not successful at ridding samples of contaminating DNA. Therefore, when performing RNA analyses on porcine tooth pulp samples, DNase treatment may be necessary to get results that accurately reflect true initial RNA levels.

The use of Ambion TURBO ${ }^{\mathrm{TM}}$ DNA-free DNase in our laboratory caused an increase in $\mathrm{Ct}$ values obtained following qRT-PCR. Higher $\mathrm{Ct}$ values indicate a loss of cDNA or RNAderived signal. Ambion's TURBO ${ }^{\mathrm{TM}}$ DNA-free DNase utilizes a removal agent that binds both the DNase and divalent cations, thus in theory, preventing them from being carried over into reverse transcription reaction. After analyzing the different DNase treatments, it was found that Ambion was the only protocol that greatly reduced the amount of cDNA detected using qRTPCR. This indicates that the removal agent is not successful at riding the entire sample of DNase. Ambion's technical support staff recommended the use of Ambion non-stick tubes to help keep DNase from getting carried over into the reaction. The non-stick tubes caused a 
greater amount of cDNA loss than the Ambion protocol alone. Non-stick tubes prevent DNase from binding to the walls of the eppendorf tubes; thus it is likely that more DNase enzyme is getting carried over into the reverse transcription reaction.

In general it was determined that heat inactivation of the DNase enzyme was more successful at ridding samples of DNA contamination without affecting cDNA. Samples should only be treated with DNAse if they contain DNA contamination higher than background noise. It is also recommended that the least amount of DNase necessary should be added to the reactions; therefore minimizing the chance that DNase may affect RNA or cDNA levels. On average DNase produces higher $\mathrm{CT}$ values which correspond to loss of some cDNA regardless of the treatment. Even if this loss is below the threshold of one, DNase should still be avoided if possible.

Overall it was determined that any manufacturer's claims need to be treated cautiously because without proper validation studies, one could be biasing their results when using DNase. For example, treating RNA samples with DNase could cause incorrect conclusions to be drawn when estimating the age of a biological stain. A loss of RNA-derived signal due to DNase treatment could affect forensic studies by placing the suspect at a crime scene at the wrong time. These types of errors must be avoided. Using DNase treatments with heat inactivation will allow a co-isolation technique to be performed to obtain both RNA and DNA from small, precious samples. The DNA component can then be analyzed with STR analysis, whereas the RNA sample can be DNase treated to obtain reliable results on multiple RNA analyses. It is suggested that, when possible, keep a portion of the RNA with no DNase treatment and determine the $\mathrm{Ct}$ values of treated and non-treated samples using RNA specific primer/probe sets. This will ensure that the DNase treatments are successful at producing DNA-free RNA samples suitable for forensic or other studies. 


\section{References}

[1] Sheridan, G.E.C. et al (1998) Detection of mRNA by Reverse Transcription-PCR as an Indicator of Viability in Escherichia coli cells. Appl. Environ. Microbiol. 64(4): 13131316

[2] Anderson, S., B. Howard, G.R. Hobbs, and C.P. Bishop (2005) A Method for Determining the Age of a Bloodstain. Foren. Sci. Int. 148:37-45

[3] Anderson, S., B. Howard, G.R. Hobbs, and C.P. Bishop (2011) Multivariate analysis for estimating the age of a bloodstain. Manuscript in press.

[4] Bauer, M., I. Gramlich, S. Polzin, and D. Patzelt (2003) Quantification of mRNA degradation as a possible indicator of postmortem interval - a pilot study. Legal Medicine 5:220-227

[5] Zhao, D. et al (2009) Postmortem quantitative mRNA analyses of death investigation in forensic pathology: An overview and prospects. Legal Medicine 11:S43-S45

[6] Sakurada, K. et al (2009) Evaluation of mRNA-based approach for identification of saliva and semen. Legal Medicine 11(3):125-128

[7] Bauer, M. and D. Patzelt (2003) Protamine mRNA as molecular marker for spermatozoa in semen stains. Int. J. Legal Med. 117:175-179

[8] Juusola, J. and J. Ballantyne (2005) Multiplex mRNA profiling for the identification of body fluids. Foren. Sci. Int. 152:1-12

[9] Swango, K.L., M.D. Timken, M.D. Chong, and M.R. Buoncristiani (2006) A Quantitative PCR Assay for the Assessment of DNA Degradation in Forensic Samples. Foren. Sci. Int. 158:14-26

[10] Opel, K.L. et al (2006) The Application of Miniplex Primer Sets in the Analysis of Degraded DNA from Human Skeletal Remains. J. Forensic Sci. 51(2):351-356

[11] Ballantyne, J. (2008, August 1). Determination of the Age (Time since Deposition) of a Biological Stain. Retrieved from the U.S. Department of Justice website: http://www.ncjrs.gov/pdffiles1/nij/grants/226811.pdf

[12] Wykes, S.M. and S.A. Krawetz (2003) Conservation of the PRIM1 $\rightarrow$ PRM2 $\rightarrow$ TNP2 Domain. DNA Sequence 14(5):359-367

[13] Govin, J. et al (2004) The Role of Histones in Chromatin Remodeling During Mammalian Spermatogenesis. Eur. J. Biochem. 271:3459-3469 
[14] Miller, D. et al (1999) A Complex Population of RNAs Exists in Human Ejaculate Spermatozoa: Implications for Understanding Molecular Aspects of Spermiogenesis. Gene 237:385-392

[15] Khara, K.K., M. Vlad, M. Griffiths, and C.R. Kennedy (1997) Human Protamines and Male Infertility. J Assist Reprod Genet 14(5):282-290

[16] Steger, K. et al (2000) Expression of Protamine-1 and -2 mRNA During Human Spermiogenesis. Molecular Human Reproduction 6(3):219-225

[17] Wykes, S.M., D.W. Visscher, and S. A. Krawetz (1997) Haploid Transcripts Persist in Mature Human Spermatozoa. Molecular Human Reproduction 3(1):15-19

[18] Dadoune, J.P., A. Pawlak, M.F. Alfonsi, and J.P. Siffroi (2005) Identification of Transcripts by Macroarrays, RT-PCR and In Situ Hybridization in Human Ejaculate Spermatozoa. Molecular Human Reproduction 11(2):133-140

[19] Hanson, E.K. and J. Ballantyne (2007) An Ultra-High Discrimination Y Chromosome Short Tandem Repeat Multiplex DNA Typing System. PLoS ONE 2(8):e688

[20] Tilford, C.A. et al (2001) A Physical Map of the Human Y Chromosome. Nature 409:943945

[21] Su, H. and Y.C. Lau (1993) Identification of the Transcriptional Unit, Structural Organization, and Promoter Sequence of the Human Sex-determining Region Y (SRY) gene, Using a Reverse Genetic Approach. Am. J. Hum. Genet. 52:24-38

[22] User Bulletin \#2-ABI PRISM 7700 Sequence Detection System: Relative Quantitation of Gene Expression (1997) Applied Biosystems (Foster City, CA)

[23] TaqMan® Gold RT-PCR Kit Protocol (2006) Applied Biosystems (Foster City, CA)

[24] TaqMan® Universal PCR Master Mix Protocol (2002) Applied Biosystems (Foster City, CA)

[25] Añez-Lingerfelt, M., G.E. Fox, and R.C. Willson (2009) Reduction of DNA contamination in RNA samples for reverse transcription-polymerase chain reaction using selective precipitation by compaction agents. Anal Biochem 384:79-85

[26] Livak, K.J. and T.D. Schmittgen (2001) Analysis of Relative Gene Expression Data Using Real-Time Quantitative PCR and the $2^{-\Delta \Delta C}$ T Method. Methods 25:402-408

[27] Horsman, K.M. et al (2005) Separation of Sperm and Epithelial Cells in a Microfabricated Device: Potential Application to Forensic Analysis of Sexual Assault Evidence. Anal. Chem. 77(3):742-749 
[28] Ivarsson, K. and B. Weijdegard (1998) Evaluation of the Effects of DNase Treatment on Signal Specificity in RT-PCR and In Situ RT-PCR. Biotechniques 25:630-638

[29] Henrich, M., K. Matt, S. Lutz-Bonengel, and U. Schmidt (2007) Successful RNA extraction from various human postmortem tissues. Int J Legal Med 121:136-142

[30] Bustin, S.A. (2002) Quantification of mRNA using real-time reverse transcription PCR (RT-PCR): trends and problems. J Mol Endocrinology 29:23-39

[31] Huang, Z., M.J. Fasco, and L.S. Kaminsky (1996) Optimization of DNase I Removal of Contaminating DNA from RNA for Use in Quantitative RNA-PCR. Biotechniques 20:1012-1020 